\title{
"Short-run and long-run effects of public debt on economic performance: Evidence from EMU countries"
}

Marta Gómez-Puig and Simón Sosvilla-Rivero 


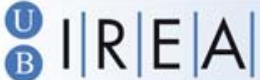

Institut de Recerca en Economia Aplicada Regional i Pública

Research Institute of Applied Economics

Universitat de Barcelona

Av. Diagonal, $690 \cdot 08034$ Barcelona

WEBSITE: www.ub.edu/irea/•CONTACT: irea@ub.edu

The Research Institute of Applied Economics (IREA) in Barcelona was founded in 2005, as a research institute in applied economics. Three consolidated research groups make up the institute: AQR, RISK and GiM, and a large number of members are involved in the Institute. IREA focuses on four priority lines of investigation: (i) the quantitative study of regional and urban economic activity and analysis of regional and local economic policies, (ii) study of public economic activity in markets, particularly in the fields of empirical evaluation of privatization, the regulation and competition in the markets of public services using state of industrial economy, (iii) risk analysis in finance and insurance, and (iv) the development of micro and macro econometrics applied for the analysis of economic activity, particularly for quantitative evaluation of public policies.

IREA Working Papers often represent preliminary work and are circulated to encourage discussion. Citation of such a paper should account for its provisional character. For that reason, IREA Working Papers may not be reproduced or distributed without the written consent of the author. A revised version may be available directly from the author.

Any opinions expressed here are those of the author(s) and not those of IREA. Research published in this series may include views on policy, but the institute itself takes no institutional policy positions. 
This paper contributes to the literature by examining the possible influence of public debt on economic performance, using data from both central and peripheral countries of the European Economic and Monetary Union for the 1960-2012 period. To this end, a simple aggregate production function augmented for public debt is estimated using the ARDL bounds testing approach. Our findings tend to support the view that the level of public debt always has a negative impact on the long-run performance of EMU countries, whilst its short-run effect may be positive in some specific cases.

JEL classification: C22, F33, H63, O40, O52

Keywords: Public debt, economic growth, bounds testing, euro area, peripheral EMU countries, central EMU countries

M. Gómez-Puig: Department of Economic Theory, Universitat de Barcelona (Barcelona, Spain) (marta.gomezpuig@ub.edu).

S. Sosvilla-Rivero: Complutense Institute for International Studies, Universidad Complutense de Madrid (Madrid, Spain) (sosvilla@,ccee.ucm.es).

\section{Acknowledgements}

This paper is based upon work supported by the Government of Spain and FEDER under grant number ECO2011-23189 and ECO2013-48326. Marta Gómez-Puig also thanks the Instituto de Estudios Fiscales for financial support (project IEF 101/2014). Simón Sosvilla-Rivero thanks the Universitat de Barcelona \& RFAIREA for their hospitality. Responsibility for any remaining errors rests with the authors. 


\section{Introduction}

This paper focuses on the effects of public debt on the economic performance of EMU countries during the period 1960 to 2012. This challenging avenue of research has been studied by economists for a long time, but has recently undergone a notable revival fuelled by the substantial deterioration of public finances in many economies as a result of the financial and economic crisis of 2008-2009 .

In particular, in the European context, the recent global recession and sovereign debt crisis has highlighted the importance of certain academic questions that policy makers may need to answer. The events of the last few years have increased the concern about the possible adverse consequences of the accumulation of public debt in EMU countries ${ }^{2}$. The debate is hotly contested, because pundits draw widely different conclusions for macroeconomic policy (in particular, in relation to their positions on economic austerity policies). Nor is there any consensus among economists: while some suggest that now is precisely the time to apply the lessons learnt during the Great Depression and that policymakers should implement expansionary fiscal policies, others argue that, since the high level of public sector leverage has a negative effect on economic growth, fiscal consolidation is fundamental to restoring confidence and improving expectations about the future evolution of the economy. The latter approach, which supports austerity measures, has been highly influential among the EMU authorities and has the support of the empirical evidence presented in some influential papers (Reinhart and Rogoff, 2010, among them).

\footnotetext{
${ }^{1}$ During the financial crisis, public deficits increased not only because economic automatic stabilizers began to work (which meant, for instance, declining revenues) but also because of the launch of fiscal stimulus packages.

${ }^{2}$ In this regard, Gómez-Puig (2013) attempts to quantify the total level of indebtedness (public and private) in all euro area countries, using a database created with the statistics provided by the European Central Bank. According to her calculations, in September 2012, total leverage (public and private) over GDP recorded levels of 710\%, 487\%, 413\%, $360 \%$ and $353 \%$ in Ireland, Portugal, Spain, Italy and Greece respectively.
} 
Therefore, the analysis in this paper centres on EMU countries - both central (Austria, Belgium, Finland, France, Germany and the Netherlands) and peripheral (Greece, Ireland, Italy, Portugal, and Spain). However, unlike previous studies [see Baum et al. (2012) or Checherita-Westphal and Rother (2012)], we do not make use of panel estimation techniques to combine the power of cross section averaging with all the subtleties of temporal dependence; rather, we explore the time series dimension of the issue to obtain further evidence based on the historical experience of each country in the sample. Our econometric methodology is data-driven, and it allows us to select the statistical model that best approximates the relationship between the variables under study for any particular country and to assess both short and long-run effects of public debt on economic performance. Finally, in a departure from previous empirical analysis, we make use of a simple aggregate production function augmented for public debt to evaluate its possible influence on economic performance.

The rest of the paper is organized as follows. In Section 2 a short literature review is provided. Section 3 presents the theoretical framework of the paper and outlines the econometric methodology. Section 4 describes our data and presents our empirical results. Finally, Section 5 summarizes the findings and offers some concluding remarks.

\section{Literature review}

Under what conditions is debt growth-enhancing? The results from the empirical literature on the relationship between public debt and economic growth are far from conclusive (see Panizza and Presbitero (2013) for a survey). While the first studies [see, for example, Modigliani (1961), Diamond (1965) and Saint-Paul (1992)] sustained that a public debt increase always contributed to economic growth, more recent work has presented totally different results. Patillo et al., (2004) conclude that whilst low levels of public debt 
positively affect economic growth, high levels have a negative impact; Schclarek (2005) does not find any significant relation between public debt and economic growth in industrial countries, whereas Kumar and Woo (2010), controlling for other factors that also influence growth, detected an inverse relationship between the two variables.

In their seminal work, Reinhart and Rogoff (2010) studied economic growth for different thresholds of public debt using a database of 44 countries over a time period spanning 200 years. Their results suggest that the relationship is weak for public debt ratios below $90 \%$ of GDP, but that, on average, growth rates decrease substantially above this threshold. However, since the publication of their paper, the $90 \%$ threshold has not only been questioned but has also been the focus of much of the debate in the literature, since not all debt accumulation episodes are similar: see Cecchetti et al. (2011), Minea and Paren (2012), Presbitero (2012), Baum et al. (2012), Checherita-Westphal and Rother (2012), Herdon et al. (2013), Égert (2013), or Afonso and Jalles (2013) to name a few.

Moreover, the recent global recession and sovereign debt crisis in Europe have stimulated an intense debate both on the effectiveness of fiscal policies and on the consequences of public debt increases, in a situation in which leverage is already very high in European economies. However, there is currently no consensus among economists in this area (see Alesina et al. 2015). Some suggest that now is precisely the time to implement expansionary fiscal policies [see, among others, Krugman (2011), Berg and Ostry (2011) or DeLong and Summers (2012)] $]^{3}$ since fiscal austerity may have been the main culprit for the recessions experienced by European countries; others claim that fiscal consolidation is essential to restore confidence in order to improve market expectations about the future evolution of the economy and therefore its rate of growth [see Cochrane (2011) or Teles and Mussolini

\footnotetext{
3 These authors state that deleveraging policies may even prove to be detrimental, depending on the fundamental variables of the economy. Their argument is currently supported by some politicians in southern Europe.
} 
(2014)]. In our reading of the empirical evidence, despite the sovereign debt crisis in the monetary union few papers have examined the relationship between debt and growth for euro area countries. The exceptions include Baum et al. (2012), Checherita-Westphal and Rother (2012), Dreger and Reimers (2013) and Antonakakis (2014). However, to our knowledge, no strong case has yet been made for analysing the incidence of debt accumulation on economic growth taking into account the particular idiosyncrasies of each euro area economy. This is the case even though the possible heterogeneity in the relationship between debt and growth across countries has recently been stressed; Eberhardt and Presbitero (2013), for instance, do not find evidence for common debt thresholds within countries over time. So, this paper aims to fill this gap in the literature. Unlike previous studies in the euro area we do not make use of panel techniques, but explore the time series dimension of the relationship in order to examine the differences within EMU countries.

\section{Theoretical framework and econometric methodology}

Since public debt can be seen as an alternative instrument for financing government expenditure without the need to raise existing taxes (which may create various sorts of growth-reducing distortions), when allocated to productive purposes debt may exhibit positive long-run effects on the growth rate of the economy through its impact on the productivity of private inputs. Indeed, Aschauer (1989) included public capital stock in the production function estimation since he claimed that the central aim of expansive fiscal policies was to improve the marginal productivity of the private sector's physical capital and labour (in order to raise the growth rate). Following his lead, other authors also took account of public capital stock in the production function [Devarajan et al. (1996), Zagler and Dürnecker (2003) or Englmann (2015), among them]. 
According to Devarajan et al. (1996), public expenditure can be divided into productive (or growth-enhancing) and unproductive (or purely consumptive) expenditure. Whilst the former, which includes physical infrastructure (roads and railways), communication, information systems (phone, internet), and education ${ }^{4}$ may have a positive impact on the growth rate of the economy, the latter does not affect the economy's long-run performance, although it may have positive short-run implications. Therefore, the impact of an increase in the government's level of indebtedness on economic growth will depend on the kind of expenditure it funds: a long-run positive effect might be expected when it is allocated to productive purposes, while otherwise we should expect a long-run negative effect on growth ${ }^{5}$.

Therefore, following Mankiw, Romer and Weil (1992), and consistent with the extensive empirical literature in this area, we begin our analysis by postulating a simple aggregate production function for the entire economy, in which government debt is included as a separate factor:

$$
Y_{t}=A_{t} F\left(K_{t}, L_{t}, H_{t}, D_{t}\right)
$$

where $Y_{t}$ is the level of output, $A_{t}$ is an index of technological progress or total factor productivity, $K_{t}$ is the stock of physical capital, $L_{t}$ is the labour input, $H_{t}$ is human capital, and $D_{t}$ is the level of public debt.

\footnotetext{
4 Although this sort of investment might not be profitable from the single firm's point of view (as private costs exceed private returns), the whole economy would nevertheless benefit enormously, which justifies public provision. For instance, Glomm and Ravikumar (1997) among others contend that both government infrastructure investment and education expenditures have a significant impact on an economy's long-term growth rate.

5 Nevertheless, some authors (see Teles and Mussolini, 2014) have stressed that the positive effect of productive expenditure on economic growth may present limitations.
} 
For simplicity, the technology is assumed to be of the Cobb-Douglas form:

$$
Y_{t}=A_{t} K_{t}^{\alpha_{1}} L_{t}^{\alpha_{2}} H_{t}^{\alpha_{3}} D_{t}^{\alpha_{4}}
$$

so that, after taking logs, and denoting by small letters the log of the corresponding capital letters, we obtain:

$$
y_{t}=\alpha_{0}+\alpha_{1} k_{t}+\alpha_{2} l_{t}+\alpha_{3} h_{t}+\alpha_{4} d_{t}
$$

where $a_{1+} a_{2}+\alpha_{3}+\alpha_{4}$ would indicate the degree of returns to scale in all four inputs.

Equation (3) will be the basis of our empirical analysis. As can be seen, it postulates a technological long-run relationship between (the log of) the level of production, (the log of) the stock of physical capital, (the log of) the labour employed, (the log of) the human capital and (the log of the public debt. This relationship can be estimated from sufficiently long time series by cointegration econometric techniques. In this paper we make use of the Autoregressive Distributed Lag (ARDL) bounds testing approach to cointegration proposed by Pesaran and Shin (1991) and Pesaran, Shin and Smith (2001).

This approach presents at least three significant advantages over the two alternatives commonly used in the empirical literature: the single-equation procedure developed by Engle and Granger (1987) and the maximum likelihood method postulated by Johansen $(1991,1995)$ which is based on a system of equations. First, both these approaches require that the variables under study are integrated of order 1 ; this inevitably requires a previous process of tests on the order of integration of the series which may lead to some uncertainty in the analysis of long-run relations. In contrast, the ARDL bounds testing approach allows the analysis of long-term relationships between variables, regardless of whether they are integrated of order $0[I(0)]$, of order $1[I(1)]$ or mutually cointegrated. This avoids some of the common pitfalls faced in the empirical analysis of time series, such as 
the lack of power of unit root tests and doubts about the order of integration of the variables examined. Second, the ARDL bounds testing approach allows a distinction to be made between the dependent variable and the explanatory variables, an obvious advantage over the method proposed by Engle and Granger; while, like the Johansen approach, it enables simultaneous estimation of the short-run and long-run components, eliminating the problems associated with omitted variables and the presence of autocorrelation. Finally, while the estimation results obtained by the methods proposed by Engle and Granger and Johansen are not robust to small samples, Pesaran and Shin (1991) show that the short-run parameters estimated using their approach are $\sqrt{T}$-consistent and the long-run parameters are super-consistent in small samples.

In our particular case, the application of the ARDL approach to cointegration involves estimating the following unrestricted error correction model (UECM):

$$
\begin{aligned}
& \Delta y_{t}=\beta+\sum_{i=1}^{p} \gamma_{i} \Delta y_{t-i}+\sum_{i=1}^{p} \omega_{i} \Delta k_{t-i}+\sum_{i=1}^{p} \varphi_{i} \Delta l_{t-i}+\sum_{i=1}^{p} v_{i} \Delta h_{t-i}+\sum_{i=1}^{p} \phi_{i} \Delta d_{t-i}+ \\
& +\lambda_{1} y_{t-1}+\lambda_{2} k_{t-1}+\lambda_{3} l_{t-1}+\lambda_{4} h_{t-1}+\lambda_{5} d_{t-1}+\varepsilon_{t}
\end{aligned}
$$

where $\Delta$ denotes the first difference operator, $\beta$ is the drift component, and $\varepsilon_{t}$ is assumed to be a white noise process. The ARDL approach estimates $(p+1)^{k}$ number of regressions to obtain the optimal lag length for each series, where $p$ is the maximum number of lags used and $k$ is the number of variables in equation (3). The optimal lag structure of the first differenced regression is selected by the Akaike Information Criterion (AIC) and the Schwarz Bayesian Criterion (SBC) to ensure that there is no serial correlation. In order to determine the existence of long-run relationship between the variables under study, Pesaran, Shin and Smith (2001) propose two alternative tests. First, an F-statistic is used to test the joint significance of the first lag of the variables in levels used in the analysis (i. e. 
$\left.\lambda_{1}=\lambda_{2}=\lambda_{3}=\lambda_{4}=\lambda_{5}=0\right)$. Furthermore, a t-statistic is used to test the individual significance of the lagged dependent variable in levels (i. e. $\lambda_{1}=0$ ).

Pesaran, Shin and Smith (2001) provide a set of critical values assuming first that the variables under study are $I(1)$ and, secondly, that such variables are $I(0)$. These authors propose a bounds testing procedure: if the calculated F-or $t$-statistics exceed the upper critical bound (UCB), we conclude in favour of a long-run relationship, regardless of the order of integration. However, if these statistics are below the lower critical bound (LCB), the null hypothesis of no cointegration cannot be rejected. Finally, if the calculated $F$ - and $t$-statistics are between $\mathrm{UCB}$ and $\mathrm{LCB}$, then the decision about cointegration is inconclusive. When the order of integration for all series is $I(1)$ then the decision is based on the UCB; and if all the series are $I(0)$, it is based on the LCB.

The test statistics based on equation (4) have a different distribution under the null hypothesis of no level relationships, depending on whether the regressors are all $I(0)$ or all I(1). Further, under both cases the distribution is non-standard. Pesaran, Shin and Smith (2001) provide critical values for the cases where all regressors are $I(0)$ and the cases where all regressors are $I(1)$, and suggest that these critical values be used as bounds for the more typical cases where the regressors are a mixture of $I(0)$ and $I(1)$.

If cointegration exists, the conditional long-run model is derived from the reduced form equation (4) when the series in first differences are jointly equal to zero (i. e., $\Delta y=\Delta k=$ $\Delta l=\Delta d=0)$. The calculation of these estimated long-run coefficients is given by:

$$
y_{t}=\delta_{1}+\delta_{2} k_{t}+\delta_{3} l_{t}+\delta_{4} h_{t}+\delta_{5} d_{t}+\xi_{t}
$$


where $\delta_{1}=\frac{-\beta}{\lambda_{1}} ; \delta_{2}=\frac{-\lambda_{2}}{\lambda_{1}} ; \delta_{3}=\frac{-\lambda_{3}}{\lambda_{1}} ; \delta_{4}=\frac{-\lambda_{4}}{\lambda_{1}} ; \delta_{5}=\frac{-\lambda_{5}}{\lambda_{1}} ;$ and $\xi_{t}$ is a random error. The standard error of these long-run coefficients can be calculated from the standard errors of the original regression using the delta method.

Finally, if a long-run relation is found, an error correction representation exists which is estimated from the following reduced form equation:

$$
\Delta y_{t}=\sum_{i=1}^{p} \theta_{i} \Delta y_{t-1}+\sum_{i=1}^{q_{1}} \varpi_{i} \Delta k_{t-1}+\sum_{i=1}^{q_{2}} \pi_{i} \Delta l_{t-1}+\sum_{i=1}^{q_{3}} \tau_{i} \Delta h_{t-1}+\sum_{i=1}^{q_{4}} \kappa_{i} \Delta d_{t-1}+\eta E C M_{t-1}(6)
$$

\section{Data and empirical results}

\subsection{Data}

We estimate equation (6) with annual data for eleven EMU countries: both central (Austria, Belgium, Finland, France, Germany and the Netherlands) and peripheral countries (Greece, Ireland, Italy, Portugal and Spain) ${ }^{6}$. Even though the ARDL-based estimation procedure used in the paper can be reliably used in small samples, we use long spans of data covering the period 1960-2012 (i.e., a total of 42 observations) to explore the dimension of historical specificity and to capture the long-run relationship associated with the concept of cointegration (see, e. g., Hakkio and Rush, 1991).

\footnotetext{
${ }^{6}$ This distinction between central and peripheral countries has been extensively used in the empirical literature. The two groups we consider roughly correspond to the distinction made by the European Commission (1995) between those countries whose currencies continuously participated in the European Exchange Rate Mechanism (ERM) from its inception and which maintained broadly stable bilateral exchange rates with each other over the sample period, and those countries whose currencies either entered the ERM later or suspended their participation in the ERM, as well as fluctuating in value to a great extent relative to the Deutschmark. These two groups are also roughly the ones found in Jacquemin and Sapir (1996), who applied multivariate analysis techniques to a wide set of structural and macroeconomic indicators, to form a homogeneous group of countries. Moreover, these two groups are basically the same as the ones found in Ledesma-Rodríguez et al. (2005) according to economic agents' perceptions of the commitment to maintain the exchange rate around a central parity in the ERM, and those identified by Sosvilla-Rivero and Morales-Zumaquero (2012) using cluster analysis when analysing permanent and transitory volatilities of EMU sovereign yields.
} 
To maintain as much homogeneity as possible for a sample of 11 countries over the course of six decades, our primary source is the European Commission's AMECO database ${ }^{7}$ covering the period 1960-2012. We then strengthen our data with the use of supplementary data sourced from International Monetary Fund (International Financial Statistics) and the World Bank (World Development Indicators). We use GDP, capital stock and public debt at 2010 market prices for the level of output $\left(Y_{t}\right)$, the stock of physical capital $\left(K_{t}\right)$ and the level of public debt $\left(D_{t}\right)$, and civilian employment and life expectancy at birth for indicators of the labour input $\left(L_{t}\right)$ and human capital $\left(H_{t}\right)^{8}$. The precise definitions and sources of the variables are given in Appendix 1.

\subsection{Preliminary results}

Before proceeding towards the ARDL cointegration exercise, we test for the order of integration of the variables by means of the Augmented Dickey-Fuller (ADF) tests. This is necessary just to ensure that none of our variables is only stationary at second differences (i. e., I(2)). The results, shown in Table 1, decisively reject the null hypothesis of nonstationarity, suggesting that both variables can be treated as first-difference stationary ${ }^{9}$.

\section{[Insert Table 1 here]}

We also compute the Kwiatkowski et al. (1992) (KPSS) tests, where the null is a stationary process against the alternative of a unit root. As argued by Cheung and Chinn (1997), the ADF and KPSS tests can be viewed as complementary, rather than in competition with one

\footnotetext{
7 http://ec.europa.eu/economy_finance/db_indicators/ameco/index_en.htm

8 Other proxies commonly used for human capital such as years of secondary education and school enrollment in secondary were available only from 1980. Additionally, the proxy years of secondary education did not change during the sample period.

${ }^{9}$ These results were confirmed using Phillips-Perron (1998) unit root tests controlling for serial correlation and the Elliott, Rothenberg, and Stock (1996) Point Optimal and Ng and Perron (2001) unit root tests for testing non-stationarity against the alternative of high persistence. These additional results are not shown here for reasons of space, but they are available from the authors upon request
} 
another; therefore, we can use the KPSS tests to confirm the results obtained by the ADF tests. As can be seen in Table 2, the results fail to reject the null hypothesis of stationarity in first-difference but strongly reject it in levels.

\section{[Insert Table 2 here]}

The single order of integration of the variables encourages the application of the ARDL bounds testing approach to examine the long-run relationship between the variables.

\subsection{Empirical results from the ARDL bounds test}

The estimation proceeds in stages. In the first stage, we specify the optimal lag length for the model (in this stage, we impose the same number of lags on all variables as in Pesaran, Shin and Smith, 2001). The ARDL representation does not require symmetry of lag lengths; each variable may have a different number of lag terms. As mentioned above, we use the AIC and SBC information criteria to guide our choice of the lag length. For the test of serial correlation in the residual, we use the maximum likelihood statistics for the first and fourth autocorrelation, denoted as $\chi_{s c}^{2}(1)$ and $\chi_{s c}^{2}(4)$ respectively. These results are not shown here to save space, but they are available from the authors upon request.

Next we test for the existence of a long-run relation between the output and its components as suggested by equation (3). Table 3 gives the values of the $F$ - and $t$-statistics for the case of unrestricted intercepts and no trends (case III in Pesaran, Shin and Smith, $2001)^{10}$. These statistics are compared with the critical value bounds provided in Tables CI and CII of Pesaran, Shin and Smith (2001) and depend on whether an intercept and/or trend is included in the estimations.

10 We also consider two additional scenarios for the deterministics: unrestricted intercepts, restricted trends; and unrestricted intercepts, unrestricted trends (cases IV and V in Pesaran, Shin and Smith, 2001). These additional results are not shown here for reasons of space, but they are available from the authors upon request. Nevertheless, our estimation results indicate that the intercepts are always statistically significant, but not the trends. 
[Insert Table 3 here]

The estimated long-run relationships between the variables are reported in Table 4.

[Insert Table 4 here]

In order to examine the short-term dynamics of the model, we estimate an error-correction model associated with the above long-run augmented production function. These results are reported in Table 5, which shows that the short-run analysis seems to pass diagnostic tests such as normality of error term, second-order residual autocorrelation and heteroskedasticity $\left(\chi_{N,}^{2} \chi_{S C}^{2}\right.$ and $\chi_{H}^{2}$ respectively).

[Insert Table 5 here]

Finally, we examine the stability of long-run coefficients using the CUSUM and CUSUM squares tests (Figures 1 and 2). These tests are applied recursively to the residuals of the error-correction model shown in Table 5. Since the test statistics remain within their critical values (at a marginal significance level of $5 \%$ ), we are able to confirm the stability of the estimated long-run equation.

\section{[Insert Figures 1 and 2 here]}

Thus, the following results can be drawn from Tables 4 and 5. First, the long-term effect of debt on economic performance is negative in all EMU countries; France (-0.5439), Spain (0.3356) and Portugal (-0.3356) are the countries with highest negative impact, and Ireland (-0.0492), Finland (-0.0490) and Germany (-0.0397) the ones with the lowest negative impact. So, according to our results the impact of an increase in the government's level of indebtedness on economic activity is always negative, regardless of the kind of expenditure (productive or unproductive) it may fund. 
Second, regarding EMU peripheral countries, it is interesting to note that in Greece, Ireland and Italy an increase in public debt has a negative effect on GDP not only in the long run but in the short run as well. In Portugal and Spain, however, in spite of its important negative impact in the long run, its effect in the short run is positive (one period lagged in the case of Portugal).

And third, with respect to EMU central countries, it is noticeable that in Germany and Finland the effect of public debt on GDP is positive in the short run (one period lagged), and negative (though very small) in the long run. Similar results are found in the case of Austria (though the long-run negative effect is larger). Finally, in the case of Belgium and France our results suggest that public debt has a negative impact on economic activity both in the short and in the long run (in the case of France, the negative long-run impact is the highest).

These results suggest that in two peripheral (Spain and Portugal) and three central countries (Germany, Finland and Austria), public debt may have been funding unproductive (or purely consumptive) expenditure. This may have had positive implications, but only in the short run (see Devarajan et al., 1996).

Nevertheless, we did not find a positive long-run relationship between public debt and output in any country. This suggests that, even though some public debt may have been funding productive expenditure, its volume was not large enough to enhance economic activity. Besides, the fact that we have explored the impact of public debt on output during a time period that covers five decades (1960-2012) and extends beyond the economic and sovereign debt crisis (see Figures 3 and 4) may have distorted the results, in view of the sudden and significant rise in European countries' public debt levels following government interventions in response to global financial crisis (not only fiscal stimulus programmes and 
bank bailouts, but also social safety nets that work as economic automatic stabilizers by responding to the increase in the unemployment rate).

\section{[Insert Figures 3 and 4 here]}

So, in the next sub-section we analyse the time-varying impact of public debt on short-term economic performance, splitting our sample into several sub-periods that were defined by the Euro Area Business Cycle Dating Committee ${ }^{11}$, based on a methodology analogous to the one used to determine the Economic Cycle Research Institute's (ECRI) international business cycle dates ${ }^{12}$. In particular, the following business cycles have been detected for EMU economies during the 1960-2012 sample period: (1) 1960-1974; (2) 1975-1992; (3) 1993-2007; and (4) 2008-2012. However, due to estimation constraints, we only re-estimate the short-run model for two sub-periods [(a) 1975-1992 and (b) 1993-2007] and analyse whether the impact of government debt on output differs between them ${ }^{13}$.

\subsection{Time-varying impact of public debt on economic performance.}

The short-run analysis for the two sub-samples, (a) 1975-1992 and (b) 1993-2007, in each EMU country is presented in Table 6.

\section{[Insert Table 6 here]}

The diagnostic tests reported in Table 6 do not show any sign of misspecification in the estimated equations. Besides, the most important results that can be drawn from this table are the following. In the case of central countries, whilst in the Netherlands public debt has a positive impact on output during the second sub-period (1993-2007), in France and Germany the effect is positive through both sub-periods (1975-1992 and 1993-2007).

\footnotetext{
11 See Center for Economic Policy Research (2014).

12 See https://www.businesscycle.com/ecri-business-cycles/international-business-cycle-dates-chronologies

13 The sudden, significant rise in government debt levels following government interventions in response to the global financial crisis beyond 2007 (see Figure 3) is another of the reasons why we do not extend the analysis beyond this date.
} 
Regarding peripheral countries we also find a positive impact of debt on output during the second sub-period (1993-2007) in the case of Greece, Ireland and Italy, and in the first one (1975-1992) in the case of Spain.

These results may qualify the findings obtained for the whole sample, which suggested that in two peripheral (Spain and Portugal) and three central countries (Germany, Finland and Austria), public debt had a positive effect on output, though only in the short run.

Therefore, taking together the short-run results obtained for the whole sample and the two sub-samples (Tables 5 and 6), we may cautiously conclude that although the effect of public debt on output is always negative in the long run, it may be positive in the short run. This appears to have been the case of Germany and Spain during the sample periods 19752007 and 1975-1992 respectively.

\section{Concluding remarks}

In this paper we have examined the possible influence of public debt on economic performance in eleven EMU countries (both central and peripheral) during the 1960-2012 period. To this end, we estimated a simple aggregate production function for total output including public debt as a separate factor for each country. Therefore, this study endeavours to fill the current research gap caused by the use of panel-data techniques to analyse the relationship between debt and output, which do not allow distinctions to be made between countries.

The results obtained by using the ARDL bounds testing approach to cointegration suggest a negative effect of public debt on output in the long run, but admit the possibility of a positive effect in the short run depending on the characteristics of the country and of the final allocation of public debt. We do not claim that the results are infallible, but we stress that they are based on widely accepted econometric tools and techniques as well as on 
sound economic logic. Nevertheless, further research is needed in order to identify the macroeconomic determinants of public debt, since its effects may differ according to its allocation: that is, to productive (or growth-enhancing) public expenditure, or to unproductive (or purely consumptive) expenditure (see Devarajan et al., 1996).

\section{Acknowledgements}

This paper is based upon work supported by the Government of Spain and FEDER under grant number ECO2011-23189 and ECO2013-48326. Marta Gómez-Puig also thanks the Instituto de Estudios Fiscales for financial support (project IEF 101/2014). Simón Sosvilla-Rivero thanks the Universitat de Barcelona \& RFA-IREA for their hospitality. Responsibility for any remaining errors rests with the authors. 
Appendix 1: Definition of the explanatory variables and data sources

\begin{tabular}{|c|c|c|}
\hline Variable & Description & Source \\
\hline Level of Output $\left(Y_{t}\right)$ & Gross domestic product at 2010 market prices & $\begin{array}{c}\text { Annual Macroeconomic Database- } \\
\text { European Commission (AMECO) }\end{array}$ \\
\hline Capital Stock $\left(K_{t}\right)$ & Net capital stock at 2010 market prices & AMECO \\
\hline Level of public debt $\left(D_{t}\right)$ & General government consolidated gross debt at & AMECO and International Monetary \\
& 2010 market prices & AMECO \\
\hline Labour input $\left(L_{t}\right)$ & Civilian employment & World Development Indicators, World \\
& & Bank \\
\hline
\end{tabular}




\section{References}

Alesina, A., Barbiero, O., Favero, C., Giavazzi, F., and Paradisi, M. (2015). Austerity in 20092013. National Bureau of Economic Research Working Paper 20827.

Afonso, A. and Jalles, J.T. (2013). Growth and productivity: The role of government debt. International Review of Economics and Finance 25: 384-407.

Antonakakis, N. (2014). Sovereign Debt and Economic Growth Revisited: The Role of (Non-) Sustainable Debt Thresholds. Vienna University, Department of Economics Working Paper Series, 187.

Aschauer, D.A. (1989). Is Pubic Expenditure Productive? Journal of Monetary Economics 23: 177200.

Baum, A., Checherita-Westphal, C. and Rother, P. (2012) Debt and Growth: New Evidence for the Euro Area. Journal of International Money and Finance 32: 809-821.

Berg, A. and Ostry, J. (2011) Inequality and Unsustainable Growth: Two Sides of the Same Coin. Staff Discussion Note 11/08, International Monetary Fund, Washington DC.

Cecchetti, S. G., Mohanty, M. and Zampolli, F. (2011) The Real Effects of Debt. Working Papers No 352, Bank for International Settlements, Basel.

Checherita-Westphal, C. and Rother, P. (2012) The Impact of High Government Debt on Economic Growth and Its Channels: An Empirical Investigation for the Euro Area. European Economic Review 56: 1392-1405.

Center for Economic Policy Research (2014). Euro Area Business Cycle Dating Committee: Euro Area Mired in Recession Pause.

Cheung, Y.-W. and Chinn, M. D. (1997) Further investigation of the uncertain unit root in GNP. Journal of Business and Economic Statistics 15, 68-73.

Cochrane, J. H. (2011) Understanding Policy in the Great Recession: Some Unpleasant Fiscal Arithmetic. European Economic Review 55: 2-30.

Delong, B.J. and Summers, L. H. (2012) Fiscal Policy in a Depressed Economy, Brookings Papers on Economic Activity, Spring: 233-274.

Devarajan, S., Swaroop, V., and Zou, H. (1996). The composition of public expenditure and economic growth. Journal of Monetary Economics 37: 313- 344.

Diamond, P. (1965) National Debt in a Neoclassical Growth Model. American Economic Review 55: $1126-1150$.

Dreger, C., and Reimers, H.E. (2013). Does euro area membership affect the relation between GDP growth and public debt? Journal of Macroeconomics 38: 481-486.

Eberhardt, M., and Presbitero, A.F. (2013). This Time They Are Different: Heterogeneity and Nonlinearity in the Relationship between Debt and Growth. International Monetary Fund Working Paper 248.

Égert, B. (2013). The 90\% Public Debt Threshold: The Rise and Fall of a Stylised Fact. OECD Working Paper 1055, Paris. 
Engle, R. F. and Granger, C. W. J. (1987) Co-integration and error correction: Representation, estimation and testing. Econometrica 55, 251-276.

Englmann, F.C. (2015). Can Public Debt Be Sustainable? - A Contribution to the Theory of the Sustainability of Public Debt. IVR Working Paper 2015/01

European Commission (1995) The Impact of Exchange-rate Movements on Trade within the Single Market. European Economy 4: 1-94.

Gómez-Puig, M. (2013) Crisis de la Deuda Soberana y Apalancamiento en la Zona Euro: Un Intento de Cuantificación. Cuadernos de Economia: Spanish Journal of Economics and Finance 36: 6783.

Glomm, G. and Ravikumar, B. (1997) Productive government expenditures and long- run growth. Journal of Economic Dynamics and Control 21, 183-204.

Hakkio, C. G. and Rush, M. (1991) Cointegration: how short is the long run? Journal of International Money and Finance 10, 571-581.

Herndon, T., Ash, M. and Pollin, R. (2013) Does High Public Debt Consistently Stifle Economic Growth? A Critique of Reinhart and Rogoff. Working Paper No. 322, Political Economy Research Institute, Amherst, MA.

Jacquemin, A. and Sapir, A. (1996) Is a European Hard Core Credible? A Statistical Analysis. Kyklos 49: 105-117.

Johansen, S. (1991) Estimation and hypothesis testing of cointegration vectors in Gaussian vector autoregressive models. Econometrica 59, 1551-1580.

Johansen, S. (1995) Likelihood-based Inference in Cointegrated Vector Autoregressive Models. Oxford University Press, Oxford.

Kumar, M. S. and Woo, J. (2010) Public Debt and Growth. Working Paper 10/174, International Monetary Fund, Washington DC.

Krugman, P. (2011) Self-defeating Austerity, New York Times, July 7.

Kwiatkowski, D., Phillips, P. C. B, Schmidt, P and Shin, Y. (1992) Testing the null hypothesis of stationary against the alternative of a unit root. Journal of Econometrics 54, 159-178.

Ledesma-Rodríguez, F., Navarro-Ibáñez, M, Pérez-Rodríguez, J. and Sosvilla-Rivero, S. (2005) Assessing the Credibility of a Target Zone: Evidence from the EMS. Applied Economics 37: 2265-2287.

Modigliani, F. (1961) Long-run Implications of Alternative Fiscal Policies and the Burden of the National Debt. Economic Journal 71: 730-755.

Minea, A. and Parent, A. (2012). Is High Public Debt always Harmful to Economic Growth? Reinhart and Rogoff and Some Complex Nonlinearities. Working Paper No. 8, Association Francaise de Cliometrie, Restinclières.

Ng, S. and Perron, P. (2001) Lag length selection and the construction of unit root tests with good size and power. Econometrica 69, 1519-1554.

Panizza, H. and Presbitero, A. F. (2013) Public Debt and Economic Growth in Advanced Economies: A Survey. Swiss Journal of Economics and Statistics 149: 175-204. 
Patillo, C., Poirson, H. and Ricci L. (2004) What Are the Channels through which External Debt Affects Growth? Working Paper 04/15, International Monetary Fund, Washington DC.

Pesaran, M. H. and Shin, Y. (1991) An autoregressive distributed lag modelling approach to cointegration analysis. In Econometrics and Economic Theory in the 20th Century: The Ragnar Frisch Centennial Symposium, S. Strom (ed.), Cambridge University Press, Cambridge.

Pesaran, M. H., Y. Shin, and Smith, R. J. (2001) Bounds testing approaches to the analysis of level relationships. Journal of Applied Econometrics 16, 289-326.

Phillips, P. C. B. and Perron, P. (1988) Testing for a unit root in times series regression. Biometrika 75, 335-346.

Presbitero, A.F. (2012) Total Public Debt and Growth in Developing Countries. European Journal of Development Research 24: 606-626.

Reinhart, C. M. and Rogoff, K. S. (2010) Growth in a Time of Debt. American Economic Review 100: 573-578.

Saint-Paul, G. (1992) Fiscal Policy in an Endogenous Growth Model. Quarterly Journal of Economics 107: 1243-1259.

Schclarek, A. (2005) Debt and Economic Growth in Developing Industrial Countries. Working Papers No. 34. Department of Economics, Lund University, Lund.

Sosvilla-Rivero, S. and Morales-Zumaquero, A. (2012) Volatility in EMU Sovereign Bond Yields: Permanent and Transitory Components. Applied Financial Economics 22: 1453-1464.

Teles. V.K. and Mussolini, C.C. (2014). Public debt and the limits of fiscal policy to increase economic growth. European Economic Review 66: 1-15

Zagler, M., and Dürnecker, G. (2003). Fiscal Policy and Economic Growth. Journal of Economic Surveys 17: 397-418. 
Table 1. Augmented Dickey-Fuller tests for unit roots.

\begin{tabular}{|c|c|c|c|c|}
\hline \multicolumn{5}{|c|}{ Panel A: I (2) versus I (1) (Variables in first differences) } \\
\hline Country & Variable & $\tau_{\tau}$ & $\tau_{\mu}$ & $\mathbf{T}$ \\
\hline \multirow[t]{5}{*}{ AT } & $\Delta y$ & --6.5127 & $-5.1999 *$ & $-2.7422 *$ \\
\hline & $\Delta \boldsymbol{k}$ & $-4.3308^{*}$ & $-3.6206^{*}$ & $-2.8238^{*}$ \\
\hline & $\Delta \mathbf{l}$ & $-5.9083 *$ & $-5.3123^{*}$ & $-4.5947 *$ \\
\hline & $\Delta \boldsymbol{h}$ & $-9.9420 *$ & $-9.9180^{*}$ & $-2.7413^{*}$ \\
\hline & $\Delta d$ & $-5.7918^{*}$ & $-5.6235^{*}$ & $-2.7181^{*}$ \\
\hline \multirow[t]{5}{*}{ BE } & $\Delta y$ & $-6.7061^{*}$ & $-5.0801 *$ & $-2.9577 *$ \\
\hline & $\Delta k$ & $-4.2892^{*}$ & $-3.7822 *$ & $-2.6954 *$ \\
\hline & $\Delta \mathbf{l}$ & $-4.8361^{*}$ & $-4.5554^{*}$ & $-4.1708^{*}$ \\
\hline & $\Delta h$ & $-11.0268^{*}$ & $-11.0715^{*}$ & $-3.2521 *$ \\
\hline & $\Delta d$ & $-7.2830^{*}$ & $-3.7436^{*}$ & $-2.7532 *$ \\
\hline \multirow[t]{5}{*}{ FI } & $\Delta y$ & $-4.8867 *$ & $-4.5320^{*}$ & $-3.3071^{*}$ \\
\hline & $\Delta k$ & $-3.7701 * *$ & $-3.8441^{*}$ & $-2.6211^{*}$ \\
\hline & $\Delta \mathbf{l}$ & $-4.5945^{*}$ & $-4.6448^{*}$ & $-4.6380 *$ \\
\hline & $\Delta \boldsymbol{h}$ & $-5.9301^{*}$ & $-4.0088^{*}$ & $-3.0615^{*}$ \\
\hline & $\Delta d$ & $-4.1571 * *$ & $-4.2012 *$ & $-3.5862 *$ \\
\hline \multirow[t]{5}{*}{ FR } & $\Delta y$ & $-4.8869^{*}$ & $-4.5320^{*}$ & $-3.3071^{*}$ \\
\hline & $\Delta \boldsymbol{k}$ & $-3.6816^{* *}$ & $-3.0692 * *$ & $-2.8730 *$ \\
\hline & $\Delta \mathbf{l}$ & $-4.8908^{*}$ & $-4.9177 *$ & $-2.9013^{*}$ \\
\hline & $\Delta \boldsymbol{h}$ & $-7.0261^{*}$ & $-7.0713^{*}$ & $-3.2521^{*}$ \\
\hline & $\Delta d$ & $-4.6158^{*}$ & $-4.6150 *$ & $-4.1180^{*}$ \\
\hline \multirow[t]{5}{*}{ GE } & $\Delta y$ & $-6.6679^{*}$ & $-5.1871^{*}$ & $-3.3196^{*}$ \\
\hline & $\Delta \boldsymbol{k}$ & $-3.7030 * *$ & $-3-6413^{*}$ & $-2.7401^{*}$ \\
\hline & $\Delta \mathbf{I}$ & $-5.9950 *$ & $-5.7201 *$ & $-5.2289 *$ \\
\hline & $\Delta \boldsymbol{h}$ & $-7.9188^{*}$ & $-7.4507^{*}$ & $-2.6810^{*}$ \\
\hline & $\Delta d$ & $-4.7909^{*}$ & $-4.4196^{*}$ & $-2.5651 * *$ \\
\hline \multirow[t]{5}{*}{ GR } & $\Delta y$ & $-4.9108^{*}$ & $-3.8706^{*}$ & $-3.5100 *$ \\
\hline & $\Delta \boldsymbol{k}$ & $-4.1123 * *$ & $-3.6180 *$ & $-2.6658^{*}$ \\
\hline & $\Delta \mathbf{I}$ & $-4.1775^{*}$ & $-3.2877 * *$ & $-2.7391 *$ \\
\hline & $\Delta \boldsymbol{h}$ & $-7.5080^{*}$ & $-6.7105^{*}$ & $-2.8612^{*}$ \\
\hline & $\Delta d$ & $-9.1968^{*}$ & $-8.5823^{*}$ & $-2.8743^{*}$ \\
\hline \multirow[t]{5}{*}{ IE } & $\Delta y$ & $-3.9471 * *$ & $-3.5356^{*}$ & $-2.7748 *$ \\
\hline & $\Delta \boldsymbol{k}$ & $-4.0129 * *$ & $-3.7324^{*}$ & $-2.6380^{*}$ \\
\hline & $\Delta \mathbf{l}$ & $-4.7243^{*}$ & $-3.9504^{*}$ & $-3.1723^{*}$ \\
\hline & $\Delta \boldsymbol{h}$ & $-5.2499^{*}$ & $-3.1738 * *$ & $-2.6364^{*}$ \\
\hline & $\Delta d$ & $-3.6018^{* *}$ & $-3.6301 *$ & $--3.1692 *$ \\
\hline \multirow[t]{5}{*}{ IT } & $\Delta y$ & $-6.9406^{*}$ & $-4.2181^{*}$ & $-2.6475^{*}$ \\
\hline & $\Delta \boldsymbol{k}$ & $-4.5159^{*}$ & $-3.5312 * *$ & $-2.7899 *$ \\
\hline & $\Delta \mathbf{l}$ & $-4.0228 * *$ & $-4.0473 *$ & $-4.0761 *$ \\
\hline & $\Delta \boldsymbol{h}$ & $-5.7923^{*}$ & $-4.0831 *$ & $-2.9108^{*}$ \\
\hline & $\Delta d$ & $-4.6082^{*}$ & $-3.6530^{*}$ & $-2.9241^{*}$ \\
\hline \multirow[t]{5}{*}{ NL } & $\Delta y$ & $-4.3834^{*}$ & $-3.4255 * *$ & $-2.6215^{*}$ \\
\hline & $\Delta \boldsymbol{k}$ & $-4.2530 *$ & $-3.1562 * *$ & $-2-6234 *$ \\
\hline & $\Delta \mathbf{I}$ & $-5.7439 *$ & $-5.8074 *$ & $-4.5647^{*}$ \\
\hline & $\Delta \boldsymbol{h}$ & $-9.0270 *$ & $-8.5068^{*}$ & $-2.9240^{*}$ \\
\hline & $\Delta d$ & $-5.3582^{*}$ & $-4.9341^{*}$ & $-3.8121^{*}$ \\
\hline \multirow[t]{5}{*}{ PT } & $\Delta y$ & $-4.7999 *$ & $-3.5718^{*}$ & $-2.5546^{* *}$ \\
\hline & $\Delta \boldsymbol{k}$ & $-4.2971^{*}$ & $-2.9443 * *$ & $-2.5840 * *$ \\
\hline & $\Delta \mathbf{l}$ & $-4.7487 *$ & $-4.7232 *$ & $-4.6853^{*}$ \\
\hline & $\Delta \boldsymbol{h}$ & $-5.7846^{*}$ & $-5.4675^{*}$ & $-2.7329 *$ \\
\hline & $\Delta d$ & $-4.0644 * *$ & $-3.9994 *$ & $-2.8629 *$ \\
\hline \multirow[t]{5}{*}{ SP } & $\Delta y$ & $-3.5807 * *$ & $-3.6355^{*}$ & $-2.6507^{*}$ \\
\hline & $\Delta \boldsymbol{k}$ & $-3.9787 * *$ & $-3.3918 * *$ & $-2.7152 *$ \\
\hline & $\Delta \mathbf{I}$ & $-4.4395 *$ & $-3.6134 *$ & $--2.7684^{*}$ \\
\hline & $\Delta \boldsymbol{h}$ & $-7.1213^{*}$ & $-6.9283^{*}$ & $-2.7529 *$ \\
\hline & $\Delta d$ & $-3.6815^{* *}$ & $-3.8129 *$ & $--2.8241 *$ \\
\hline
\end{tabular}


Table 1 (Continued)

\begin{tabular}{|c|c|c|c|c|}
\hline \multicolumn{5}{|c|}{ Panel B: I (1) versus I (0) (Variables in levels) } \\
\hline Country & Variable & $\tau_{\tau}$ & $\tau_{\mu}$ & $\mathbf{T}$ \\
\hline \multirow[t]{5}{*}{ AT } & $y$ & -1.3393 & -2.4451 & 2.3954 \\
\hline & $\boldsymbol{k}$ & -0.6238 & -2.4602 & -0.0349 \\
\hline & $I$ & -2.1348 & 1.6423 & 3.5707 \\
\hline & h & -2.2066 & -0.2614 & 1.9615 \\
\hline & d & -3.0156 & 1.1100 & 3.5156 \\
\hline \multirow[t]{5}{*}{$\mathbf{B E}$} & $y$ & -2.0986 & $-2-1541$ & 1.7470 \\
\hline & $k$ & -1.7936 & -2.5072 & 0.6156 \\
\hline & $I$ & -1.3175 & 0.3671 & 1.8619 \\
\hline & $h$ & -3.1226 & -1.0485 & 0.6528 \\
\hline & $d$ & -1.3880 & -1.2012 & 1.3224 \\
\hline \multirow[t]{5}{*}{ FI } & $y$ & -1.4191 & -1.8605 & 2.5771 \\
\hline & $k$ & -1.7451 & -2.3438 & 0.9656 \\
\hline & $I$ & --3.0428 & -2.4541 & 0.5916 \\
\hline & $h$ & -2.4975 & 0.2117 & 2.7514 \\
\hline & $d$ & -1.8771 & -0.7870 & 1.5818 \\
\hline \multirow[t]{5}{*}{ FR } & $y$ & -1.5816 & -2.0082 & 1.3944 \\
\hline & $k$ & -1.8122 & -2.3024 & 0.7936 \\
\hline & $I$ & -1.9436 & -1.6164 & 0.9568 \\
\hline & $h$ & -3.1226 & 0.4458 & 2.5123 \\
\hline & $d$ & $-3-0927$ & -0.1796 & 1.8067 \\
\hline \multirow[t]{5}{*}{ GE } & $y$ & -1.5816 & -2.0082 & 1.3944 \\
\hline & $k$ & -1.8122 & -2.3024 & 0.7936 \\
\hline & $I$ & -1.9436 & -1.6164 & 0.9568 \\
\hline & h & -2.2338 & -1.5692 & 1.3238 \\
\hline & $d$ & -0.3146 & -1.6901 & 2.5730 \\
\hline \multirow[t]{5}{*}{ GR } & $y$ & -1.0010 & -2.3408 & 1.3569 \\
\hline & $k$ & -1.5597 & -2.4808 & -0.5418 \\
\hline & $I$ & -2.2558 & -2.0543 & -0.3281 \\
\hline & h & -1.5812 & -0.7191 & 1.5861 \\
\hline & $d$ & -1.1751 & -1.4518 & 1.1216 \\
\hline \multirow[t]{5}{*}{ IE } & $y$ & -1.9512 & -0.8449 & 2.2557 \\
\hline & $k$ & -3.0149 & -1.6303 & 0.9326 \\
\hline & $I$ & -1.9729 & -0.3138 & 1.3973 \\
\hline & $h$ & -2.1733 & -2.0531 & -1.2554 \\
\hline & $d$ & -2.2974 & -0.7554 & 1.4304 \\
\hline \multirow[t]{5}{*}{ IT } & $y$ & $-2-1720$ & -0.5518 & 2.3052 \\
\hline & $k$ & -2.4669 & -0.5135 & 0.6318 \\
\hline & $I$ & -3.1509 & -1.2592 & 0.3692 \\
\hline & $h$ & -0.5641 & -1.4814 & 2.0789 \\
\hline & $d$ & -0.5985 & -2.4603 & 2.1287 \\
\hline \multirow[t]{5}{*}{ NL } & $y$ & -1.8167 & -2.4855 & 2.2671 \\
\hline & $k$ & -2.7912 & -2.4371 & 0.1985 \\
\hline & $I$ & -1.2728 & -0.2763 & 1.7524 \\
\hline & h & -2.2529 & -0.1643 & 1.9099 \\
\hline & $d$ & -1.3819 & $-0,1586$ & 1.0583 \\
\hline \multirow[t]{5}{*}{ PT } & $y$ & -0.7924 & -2.1028 & 1.8841 \\
\hline & $k$ & 0.5611 & -2.0484 & 0.1611 \\
\hline & $I$ & -1.3539 & -1.1791 & 0.7371 \\
\hline & h & -1.8500 & -2.3604 & 1.7143 \\
\hline & $d$ & -1.0314 & -1.0858 & 1.2001 \\
\hline \multirow[t]{5}{*}{ SP } & $y$ & -1.5694 & -2.1594 & 1.5243 \\
\hline & $k$ & -1.9370 & -2.1556 & 1.6316 \\
\hline & $I$ & -2.4506 & -1.6025 & 0.4907 \\
\hline & $h$ & -1.7033 & -1.4070 & 1.7045 \\
\hline & $d$ & -2.2347 & -0.3025 & 1.8015 \\
\hline
\end{tabular}

Notes: The ADF statistic is a test for the null hypothesis of a unit root.

$\tau_{\tau}, \tau_{\mu}$ and $\tau$ denote the ADF statistics with drift and trend, and with and without drift respectively.

$*$ and $* *$ denote significance at the $1 \%$ and $5 \%$ levels respectively. Critical values based on MacKinnon (1996)

AT, BE, FI, FR, GE, GR, IE, IT, NL, PT and SP stand for Austria, Belgium, Finland, France, Germany,

Greece, Ireland, Italy, the Netherlands, Portugal and Spain respectively. 
Table 2. KPSS tests for stationarity

\begin{tabular}{|c|c|c|c|}
\hline \multicolumn{4}{|c|}{ Panel A: I (2) versus I (1) (Variables in first differences) } \\
\hline Country & Variable & $\tau_{\tau}$ & $\tau_{\mu}$ \\
\hline \multirow[t]{5}{*}{ AT } & $\Delta y$ & 0.0812 & 0.3165 \\
\hline & $\Delta \boldsymbol{k}$ & 0.0675 & 0.0304 \\
\hline & $\Delta I$ & 0.1068 & 0.3145 \\
\hline & $\Delta \boldsymbol{h}$ & 0.1023 & 0.1011 \\
\hline & $\Delta d$ & 0.1129 & 0.2232 \\
\hline \multirow[t]{5}{*}{ BE } & $\Delta y$ & 0.1118 & 0.3379 \\
\hline & $\Delta \boldsymbol{k}$ & 0.0580 & 0.3120 \\
\hline & $\Delta I$ & 0.0943 & 0.3108 \\
\hline & $\Delta \boldsymbol{h}$ & 0.0938 & 0.0936 \\
\hline & $\Delta d$ & 0.1073 & 0.2062 \\
\hline \multirow[t]{5}{*}{ FI } & $\Delta y$ & 0.0679 & 0.3146 \\
\hline & $\Delta \boldsymbol{k}$ & 0.1125 & 0.3560 \\
\hline & $\Delta I$ & 0.0596 & 0.0611 \\
\hline & $\Delta \boldsymbol{h}$ & 0.0820 & 0.0892 \\
\hline & $\Delta d$ & 0.1033 & 0.1060 \\
\hline \multirow[t]{5}{*}{ FR } & $\Delta y$ & 0.0679 & 0.3126 \\
\hline & $\Delta \boldsymbol{k}$ & 0.1239 & 0.2678 \\
\hline & $\Delta I$ & 0.0784 & 0.0779 \\
\hline & $\Delta \boldsymbol{h}$ & 0.0934 & 0.0936 \\
\hline & $\Delta d$ & 0.1032 & 0.1938 \\
\hline \multirow[t]{5}{*}{ GE } & $\Delta y$ & 0.1118 & 0.3324 \\
\hline & $\Delta \boldsymbol{k}$ & 0.1075 & 0.3144 \\
\hline & $\Delta I$ & 0.1110 & 0.2663 \\
\hline & $\Delta \boldsymbol{h}$ & 0.1042 & 0.3154 \\
\hline & $\Delta d$ & 0.1121 & 0.3270 \\
\hline \multirow[t]{5}{*}{ GR } & $\Delta y$ & 0.1065 & 0.3143 \\
\hline & $\Delta \boldsymbol{k}$ & 0.1107 & 0.3385 \\
\hline & $\Delta I$ & 0.1065 & 0.1740 \\
\hline & $\Delta \boldsymbol{h}$ & 0.0636 & 0.3166 \\
\hline & $\Delta d$ & 0.0496 & 0.3061 \\
\hline \multirow[t]{5}{*}{ IE } & $\Delta y$ & 0.1114 & 1.1288 \\
\hline & $\Delta \boldsymbol{k}$ & 0.0697 & 0.1748 \\
\hline & $\Delta I$ & 0.1017 & 0.2174 \\
\hline & $\Delta \boldsymbol{h}$ & 0.0598 & 0.3140 \\
\hline & $\Delta d$ & 0.1082 & 0.1076 \\
\hline \multirow[t]{5}{*}{ IT } & $\Delta y$ & 0.0826 & 0.3291 \\
\hline & $\Delta k$ & 0.0864 & 0.3267 \\
\hline & $\Delta I$ & 0.0751 & 0.1335 \\
\hline & $\Delta \boldsymbol{h}$ & 0.1052 & 0.2715 \\
\hline & $\Delta d$ & 0.0891 & 0.3154 \\
\hline \multirow[t]{5}{*}{ NL } & $\Delta y$ & 0.0972 & 0.2974 \\
\hline & $\Delta k$ & 0.0912 & 0.3146 \\
\hline & $\Delta I$ & 0.1015 & 0.1524 \\
\hline & $\Delta \boldsymbol{h}$ & 0.0648 & 0.2608 \\
\hline & $\Delta d$ & 0.0992 & 0.2619 \\
\hline \multirow[t]{5}{*}{ PT } & $\Delta y$ & 0.0648 & 0.3184 \\
\hline & $\Delta \boldsymbol{k}$ & 0.1039 & 0.2679 \\
\hline & $\Delta I$ & 0.1017 & 0.1912 \\
\hline & $\Delta \boldsymbol{h}$ & 0.0853 & 0.2618 \\
\hline & $\Delta d$ & 0-1044 & 0.2150 \\
\hline \multirow[t]{5}{*}{ SP } & $\Delta y$ & 0.1175 & 0.2670 \\
\hline & $\Delta k$ & 0.0639 & 0.2528 \\
\hline & $\Delta I$ & 0.0878 & 0.1125 \\
\hline & $\Delta \boldsymbol{h}$ & 0.1150 & 0.2207 \\
\hline & $\Delta d$ & 0.0806 & 0.0790 \\
\hline
\end{tabular}


Table 2 (Continued)

\begin{tabular}{|c|c|c|c|}
\hline \multicolumn{4}{|c|}{ Panel B: I (1) versus I (0) (Variables in levels) } \\
\hline Country & Variable & $\tau_{\tau}$ & $\tau_{\mu}$ \\
\hline \multirow[t]{5}{*}{ AT } & $y$ & $0.2249 *$ & $0.8641^{*}$ \\
\hline & $\boldsymbol{k}$ & $0.2487 *$ & $0.8682 *$ \\
\hline & $l$ & $0.2198 *$ & $0.8092 *$ \\
\hline & $\boldsymbol{h}$ & $0.2470 *$ & $0.8737^{*}$ \\
\hline & d & $0.2261 *$ & $0.8394^{*}$ \\
\hline \multirow[t]{5}{*}{ BE } & $y$ & $0.2171 *$ & $0.8634^{*}$ \\
\hline & $\boldsymbol{k}$ & $0.2335^{*}$ & $0.8706^{*}$ \\
\hline & l & $0.2238 *$ & $0.8244^{*}$ \\
\hline & $h$ & $0.2368 *$ & $0.8749 *$ \\
\hline & $d$ & $0.2634 *$ & $0.7943^{*}$ \\
\hline \multirow[t]{5}{*}{ FI } & $y$ & $0.2199 *$ & $0.8604^{*}$ \\
\hline & $k$ & $0.2568 *$ & $0.8670^{*}$ \\
\hline & $I$ & $0.2776^{*}$ & $0.5317 * *$ \\
\hline & h & $0.2950 *$ & $0.8720^{*}$ \\
\hline & $d$ & $0.2386^{*}$ & $0.7864 *$ \\
\hline \multirow[t]{5}{*}{ FR } & $y$ & $0.2349 *$ & $0.8648^{*}$ \\
\hline & $k$ & $0.2419 *$ & $0.8593^{*}$ \\
\hline & $I$ & $0.2195^{*}$ & $0.9126^{*}$ \\
\hline & $h$ & $0.1995 * *$ & $0.8604^{*}$ \\
\hline & $d$ & $0.1532 * *$ & $0.8377^{*}$ \\
\hline \multirow[t]{5}{*}{ GE } & $y$ & $0.2349 *$ & $0.8648^{*}$ \\
\hline & $k$ & $0.2419 *$ & $0.8593 *$ \\
\hline & $I$ & $0.2195^{*}$ & $0.9126^{*}$ \\
\hline & h & $0.1763 * *$ & $0.8788^{*}$ \\
\hline & $d$ & $0.2226^{*}$ & $0.8645^{*}$ \\
\hline \multirow[t]{5}{*}{ GR } & $y$ & $0.1885 * *$ & 0.8998* \\
\hline & $k$ & $0.2449 *$ & $0.8242 *$ \\
\hline & $I$ & $0.2038 * *$ & $0.7367^{*}$ \\
\hline & $h$ & $0.2352 *$ & $0.8741^{*}$ \\
\hline & $d$ & $0.1988 * *$ & $0.8221^{*}$ \\
\hline \multirow[t]{5}{*}{ IE } & $y$ & $0.1786 * *$ & $0.8617^{*}$ \\
\hline & $k$ & $0.1889 *$ & $0.8693^{*}$ \\
\hline & $l$ & $0.2182 *$ & $0.7515^{*}$ \\
\hline & $h$ & $0.2235^{*}$ & $0.8038^{*}$ \\
\hline & $d$ & $0.1988 * *$ & $0.8926^{*}$ \\
\hline \multirow[t]{5}{*}{ IT } & $y$ & $0.2442 *$ & $0.8301^{*}$ \\
\hline & $k$ & $0.2604 *$ & $0.8597^{*}$ \\
\hline & $I$ & $0.2762 *$ & $0.7464^{*}$ \\
\hline & h & $0.2135 * *$ & $0.8789^{*}$ \\
\hline & $d$ & $0.2440 *$ & $0.8250^{*}$ \\
\hline \multirow[t]{5}{*}{ NL } & $y$ & $0.2164 *$ & $0.8650^{*}$ \\
\hline & $k$ & $0.2243 *$ & 0.8592 \\
\hline & $I$ & $0.1628 * *$ & $0.8434^{*}$ \\
\hline & $h$ & $0.1509 * *$ & $0.8612 *$ \\
\hline & $d$ & $0.1561 * *$ & $0.9626^{*}$ \\
\hline \multirow[t]{5}{*}{ PT } & $y$ & $0.2331 *$ & $0.8541^{*}$ \\
\hline & $k$ & $0.1533 * *$ & $0.8666^{*}$ \\
\hline & $I$ & $0.2141 * *$ & $0.7869^{*}$ \\
\hline & $\boldsymbol{h}$ & $0.2337^{*}$ & $0.8722 *$ \\
\hline & $d$ & $0.1048^{*}$ & $0.8334^{*}$ \\
\hline \multirow[t]{5}{*}{ SP } & $y$ & $0.1694 * *$ & $0.8610^{*}$ \\
\hline & $k$ & $0.1643 * *$ & $0.8772 *$ \\
\hline & $I$ & $0.1983 * *$ & $0.7596^{*}$ \\
\hline & $\boldsymbol{h}$ & $0.1926^{* *}$ & $0.8762 *$ \\
\hline & $d$ & $0.2987^{*}$ & $0.8994^{*}$ \\
\hline
\end{tabular}

Notes: The KPSS statistic is a test for the null hypothesis of stationarity.

$\tau_{\tau}$ and $\tau_{\mu}$ denote the KPSS statistics with drift and trend, and with drift respectively.

$*$ and $* *$ denote significance at the $1 \%$ and $5 \%$ levels respectively. Asymptotic critical values based on

Kwiatkowski et al. (1992. Table 1)

AT, BE, FI, FR, GE, GR, IE, IT, NL, PT and SP stand for Austria, Belgium, Finland, France, Germany, Greece, Ireland, Italy, the Netherlands, Portugal and Spain respectively. 
Table 3. $F$ - and $t$-statistics for testing the existence of the long-run model

\begin{tabular}{|c|c|c|c|}
\hline \multirow{2}{*}{ Country } & \multicolumn{3}{|c|}{ Bound testing to cointegration } \\
\cline { 2 - 4 } & $\mathbf{A R D L}\left(\mathbf{p}, \mathbf{q}_{1}, \mathbf{q}_{\mathbf{2}}, \mathbf{q}_{\mathbf{3}}, \mathbf{q}_{\mathbf{4}}, \mathbf{q}_{\mathbf{5}}\right)$ & $\boldsymbol{F}$-statistic & $\boldsymbol{t}$-statistic \\
\hline AT & $(4,3,3,4,4)$ & $6.8148^{*}$ & $-5.2908^{*}$ \\
\hline BE & $(1,2,4,4,0)$ & $5.0451^{* *}$ & $-3.7093^{* *}$ \\
\hline FI & $(1,4,3,1,2)$ & $5.0352^{* *}$ & $-3.8220^{* *}$ \\
\hline FR & $(1,0,2,4,3)$ & $4.1633^{* *}$ & $-3.8685^{* *}$ \\
\hline GE & $(2,2,1,0,2)$ & $6.0071^{*}$ & $-4.7023^{*}$ \\
\hline GR & $(1,3,0,0,0)$ & $4.5088^{* *}$ & $-3.6953^{* *}$ \\
\hline IE & $(1,2,1,0,0)$ & $4.6117^{* *}$ & $-3.7436^{* *}$ \\
\hline IT & $(3,2,0,4,1)$ & $5.3960^{*}$ & $-3.6283^{* *}$ \\
\hline NL & $(1,4,3,4,4)$ & $6.7727^{*}$ & $-4.2859^{*}$ \\
\hline PT & $(1,3,3,0,2)$ & $4.3225^{* *}$ & $-3.8598^{* *}$ \\
\hline SP & $(1,3,2,0,3)$ & $4.3497^{* *}$ & $-4.0635^{* *}$ \\
\hline
\end{tabular}

Notes:

$\mathrm{p}, \mathrm{q}_{1}, \mathrm{q}_{2}, \mathrm{q}_{3}, \mathrm{q}_{4}$ and $\mathrm{q}_{5}$ denote respectively the optimal lag length for $\Delta \mathrm{y}_{\mathrm{t}-\mathrm{i}}, \Delta \mathrm{k}_{\mathrm{t}-\mathrm{i}}, \Delta \mathrm{l}_{\mathrm{t}-\mathrm{i}}, \Delta \mathrm{h}_{\mathrm{t}-\mathrm{i}}$ and $\Delta \mathrm{d}_{\mathrm{t}-\mathrm{i}}$ in the UECM model (4) without deterministic trend.

${ }^{*}$ and ${ }^{* *}$ indicate that the calculated $F$ - and $t$-statistics are above the upper critical bound at $1 \%$ and $5 \%$ respectively.

AT, BE, FI, FR, GE, GR, IE, IT, NL, PT and SP stand for Austria, Belgium, Finland, France, Germany, Greece, Ireland, Italy, the Netherlands, Portugal and Spain respectively. 
Table 4. Long-run analysis

\begin{tabular}{|c|c|}
\hline Country & Estimation results \\
\hline $\mathbf{A T}$ & $\begin{array}{r}y_{t}=-0.0041+0.2964 k_{t}+0.3278 l_{t}+0.0855 h_{t}-0.1288 d_{t} \\
(-3.0331)(6.6280)(6.1756)(2.8922)(-4.3352)\end{array}$ \\
\hline $\mathbf{B E}$ & $\begin{array}{r}y_{t}=-0.0982+0.3963 k_{t}+0.4515 l_{t}+0.4210 h_{t}-0.0621 d_{t} \\
(-3.2144)(6.0705)(7.7879)(2.9783)(-5.5117)\end{array}$ \\
\hline FI & $\begin{aligned} y_{t}= & -0.0632+0.4261 k_{t}+0.4112 l_{t}+0.5375 h_{t}-049021 d_{t} \\
& (-3.5612)(5.6646)(7.2917)(4.13723)(-5.1371)\end{aligned}$ \\
\hline FR & $\begin{array}{r}y_{t}=-0.0504+0.4288_{t}+0.4277 l_{t}+0.5068 h_{t}-0.5439 d_{t} \\
(-3.6212)(5.8255)(3.8349)(3.9981)(-5.8665)\end{array}$ \\
\hline GE & 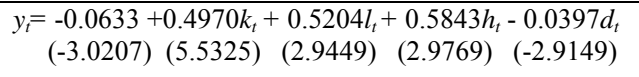 \\
\hline GR & 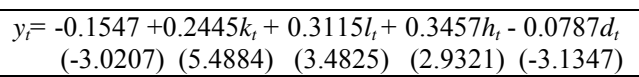 \\
\hline IE & $\begin{aligned} y_{t}= & 0.3738+0.2324 k_{t}+0.3945 l_{t}+0.1311 h_{t}-0.0492 d_{t} \\
& (2.9965)(6.1718)(3.5311) \quad(3.1237)(-7.7831)\end{aligned}$ \\
\hline IT & $\begin{array}{c}y_{t}=0.2315+0.3117 k_{t}+0.4720 l_{t}+0.1422 h_{t}-0.0831 d_{t} \\
(-3.1429)(5.8428)(6.3747) \quad(3.7232)(-6.7227)\end{array}$ \\
\hline NL & $\begin{aligned} y_{t}= & 0.0222+0.4435 k_{t}+0.3576 l_{t}+0.3571 h_{t}-0.0966 d_{t} \\
& (3.0545)(6.2867)(6.3197)(4.1977)(-7.3175)\end{aligned}$ \\
\hline PT & $\begin{array}{c}y_{t}=0.2740+0.3297 k_{t}+0.3732_{t}+0.2054 h_{t}-0.3536 d_{t} \\
(3.0336)(4.2039)(2.9423)(2.9473)(-6.3360) \\
\end{array}$ \\
\hline SP & $\begin{array}{r}y_{t}=-0.0615+0.4891 k_{t}+0.3241_{t}+0.3527 h_{t}-0.3356 d_{t} \\
(-3.0515)(7.3996)(4.0399)(3.3946)(-4.8721)\end{array}$ \\
\hline
\end{tabular}

Notes: In the ordinary brackets below the parameter estimates are the corresponding $t$-statistics.

AT, BE, FI, FR, GE, GR, IE, IT, NL, PT and SP stand for Austria, Belgium, Finland, France, Germany, Greece, Ireland, Italy, the Netherlands, Portugal and Spain respectively. 
Table 5. Short-run analysis: Whole sample

\begin{tabular}{|c|c|c|c|c|c|c|}
\hline Country & & $\begin{array}{c}\text { Adjusted } \\
\mathbf{R}^{2} \\
\end{array}$ & $\begin{array}{l}\text { DW } \\
\text { Test }\end{array}$ & $\chi_{\mathrm{N}}^{2}$ & $\chi_{\mathrm{sC}}^{2}$ & $\chi_{\mathrm{H}}^{2}$ \\
\hline AT & $\begin{aligned} \Delta y_{\mathrm{t}}= & 0.3357 \Delta y_{\mathrm{t}-1}+0.2273 \Delta y_{\mathrm{t}-2}+3.4635 \Delta k_{\mathrm{t}}+1.6406 \Delta k_{\mathrm{t}-1}+ \\
& (4.9587) \quad(3.9848) \quad(7.1120) \quad(3.2281) \\
& +0.5122 \Delta l_{\mathrm{t}}+1.8360 \Delta h_{\mathrm{t}-1}-0.1050 \Delta d_{\mathrm{t}}+0.1169 \Delta d_{\mathrm{t}-1} \\
& (4.2105) \quad(3.8970) \quad(-3.5605) \\
& +0.0771 \Delta d_{\mathrm{t}-3}-0.7184 E C M_{\mathrm{t}-1} \\
& (3.0602) \quad(-7.5397)\end{aligned}$ & 0.8052 & 2.1035 & $\begin{array}{c}1.3631 \\
{[0.5058]}\end{array}$ & $\begin{array}{c}0.4403 \\
{[0.8024]}\end{array}$ & $\begin{array}{c}6.7833 \\
{[0.7457]}\end{array}$ \\
\hline BE & 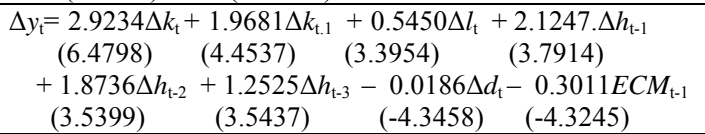 & 0.6991 & 2.1682 & $\begin{array}{c}0.7188 \\
{[0.6980]}\end{array}$ & $\begin{array}{c}1.6363 \\
{[0.4412]}\end{array}$ & $\begin{array}{c}8.7743 \\
{[0.5536]}\end{array}$ \\
\hline FI & 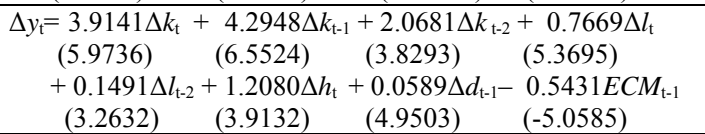 & 0.8947 & 2.1812 & $\begin{array}{c}1.8337 \\
{[0.3998]}\end{array}$ & $\begin{array}{c}0.6935 \\
{[0.7070]}\end{array}$ & $\begin{array}{c}8.3739 \\
{[0.3978]}\end{array}$ \\
\hline FR & $\begin{array}{l}\Delta y_{\mathrm{t}}=0.5483 \Delta k_{\mathrm{t}}+2.7066 \Delta l_{\mathrm{t}}+1.3583 \Delta l_{\mathrm{t}-2}+2.7571 \Delta h_{\mathrm{t}-1} \\
\quad(4.1446) \quad(6.7447) \quad(3.2368) \\
\quad-0.0540 \Delta d_{\mathrm{t}-1}-0.1594 E C M_{\mathrm{t}-1} \\
\quad(-3.2524) \quad(-4.7831)\end{array}$ & 0.6250 & 2.0703 & $\begin{array}{c}1.0284 \\
{[0.5980]}\end{array}$ & $\begin{array}{c}2.7751 \\
{[0.2497]}\end{array}$ & $\begin{array}{c}11.6117 \\
{[0.1514]}\end{array}$ \\
\hline GE & $\begin{aligned} \Delta y_{\mathrm{t}}= & 0.1245 \Delta y_{\mathrm{t}-1}+4.5310 \Delta k_{\mathrm{t}}+2.9485 \Delta k_{\mathrm{t}-1}+0.6069 \Delta l_{\mathrm{t}} \\
& (3.4013) \quad(6.2536) \quad(-4.8966) \quad(5.0089) \\
& +0.3283 \Delta h_{\mathrm{t}}+0.0888 \Delta d_{\mathrm{t}-1}-0.5431 E C M_{\mathrm{t}-1} \\
& (3.5278) \quad(3.3255) \quad(-5.7911)\end{aligned}$ & 0.8654 & 2.0727 & $\begin{array}{c}1.7700 \\
{[0.4127]}\end{array}$ & $\begin{array}{c}2.0859 \\
{[0.3524]}\end{array}$ & $\begin{array}{c}8.8985 \\
{[0.3509]}\end{array}$ \\
\hline GR & 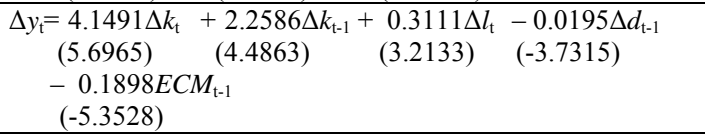 & 0.8233 & 2.0170 & $\begin{array}{c}1.6641 \\
{[0.4352]}\end{array}$ & $\begin{array}{c}1.7768 \\
{[0.4113]}\end{array}$ & $\begin{array}{c}2.7153 \\
{[0.7438]}\end{array}$ \\
\hline IE & $\begin{aligned} \Delta y_{\mathrm{t}}= & 4.1491 \Delta k_{\mathrm{t}-1}+0.5946 \Delta l_{\mathrm{t}}+3.6624 \Delta h_{\mathrm{t}-1} \\
& (4.2518) \quad(5.2966) \quad(3.3309) \\
- & 0.0770 \Delta d_{\mathrm{t}}-0.0750 E C M_{\mathrm{t}-1} \\
& (-3.9022) \quad(-6.8543)\end{aligned}$ & 0.6679 & 1.9876 & $\begin{array}{c}0.4433 \\
{[0.8012]}\end{array}$ & $\begin{array}{c}2.6952 \\
{[0.2599]}\end{array}$ & $\begin{array}{c}6.6772 \\
{[0.2458]}\end{array}$ \\
\hline IT & 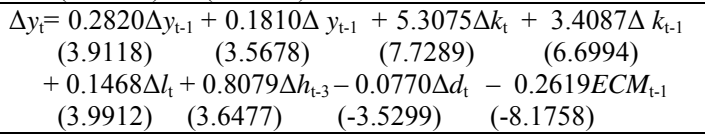 & 0,8933 & 1.9866 & $\begin{array}{c}0.9128 \\
{[0.6335]}\end{array}$ & $\begin{array}{c}5.5305 \\
{[0.0630]}\end{array}$ & $\begin{array}{c}13.3690 \\
{[0.0998]}\end{array}$ \\
\hline 65 & 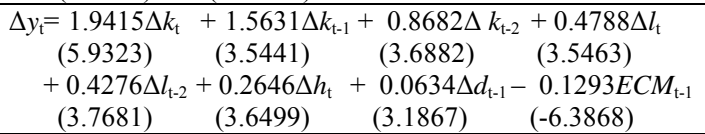 & 0.7258 & 2.1636 & $\begin{array}{c}1.3451 \\
{[0.5104]}\end{array}$ & $\begin{array}{c}2,3736 \\
{[0.3052]}\end{array}$ & $\begin{array}{c}4.8974 \\
{[0.7685]}\end{array}$ \\
\hline SP & 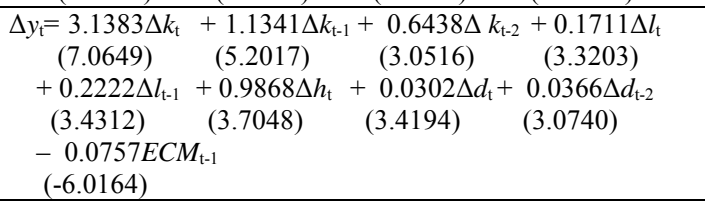 & 0.9213 & 2.1052 & $\begin{array}{c}2.9858 \\
{[0.2247]}\end{array}$ & $\begin{array}{c}2.3263 \\
{[0.3125]}\end{array}$ & $\begin{array}{c}10.2919 \\
{[0.3274]}\end{array}$ \\
\hline
\end{tabular}

Notes: AT, BE, FI, FR, GE, GR, IE, IT, NL, PT and SP stand for Austria, Belgium, Finland, France, Germany, Greece, Ireland, Italy, the Netherlands, Portugal and Spain respectively.

In the ordinary brackets below the parameter estimates are the corresponding $t$-statistics.

$\chi^{2} \mathrm{~N}, \chi^{2} \mathrm{SC}$ and $\chi^{2} \mathrm{H}$ are the Jarque-Bera test for normality, the Breusch-Godfrey LM test for second-order serial correlation and the Breusch-Pagan-Godfrey test for heteroskedasticity. In the square brackets, the associated probability values are given. 
Table 6. Short-run analysis: Sub-samples

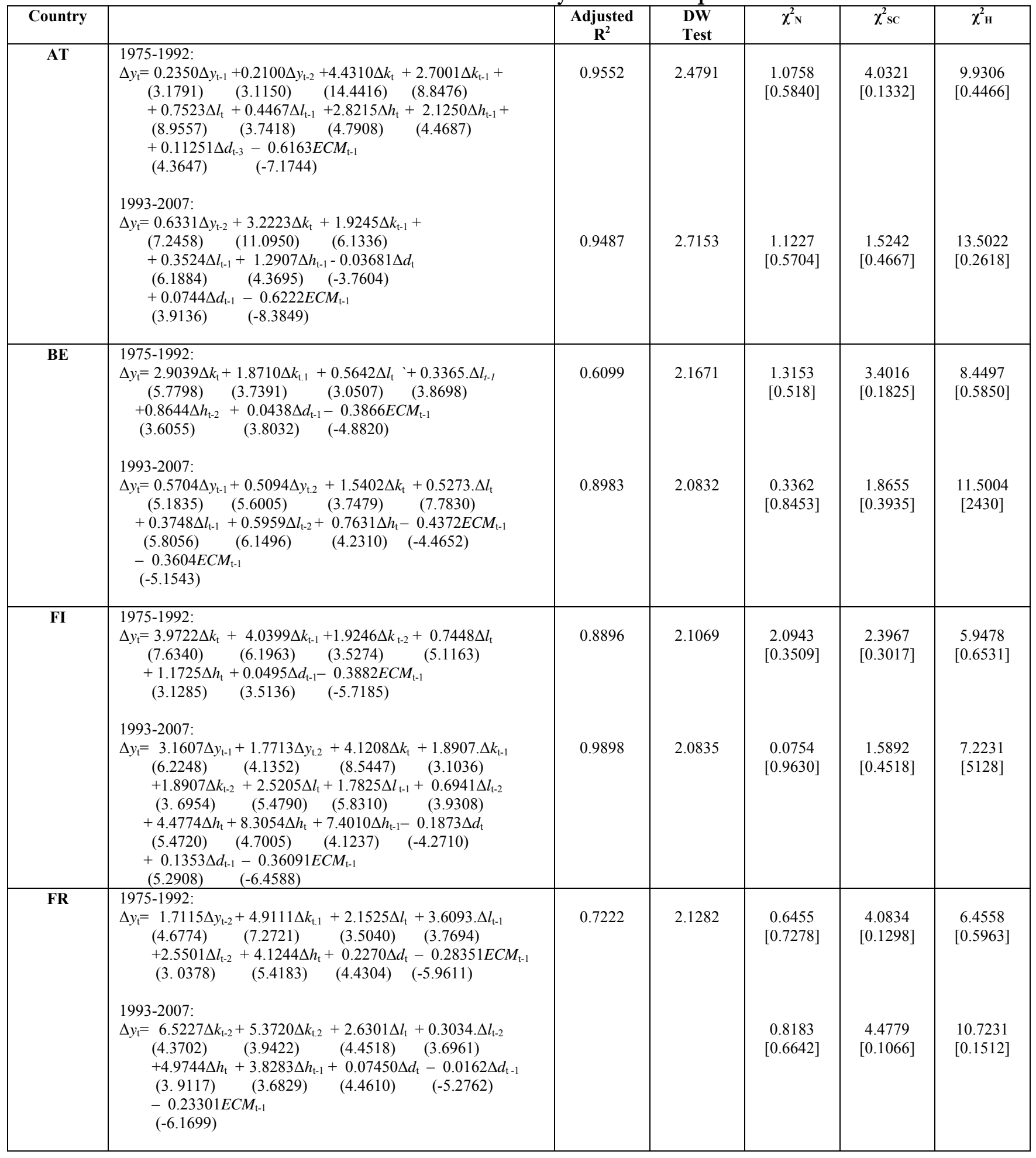


Table 6 (continued)

\begin{tabular}{|c|c|c|c|c|c|c|}
\hline Country & & $\begin{array}{c}\text { Adjusted } \\
\mathbf{R}^{2}\end{array}$ & $\begin{array}{l}\text { DW } \\
\text { Test }\end{array}$ & $\chi_{\mathrm{N}}^{2}$ & $\chi^{2} \mathrm{sc}$ & $\chi_{H}^{2}$ \\
\hline GE & 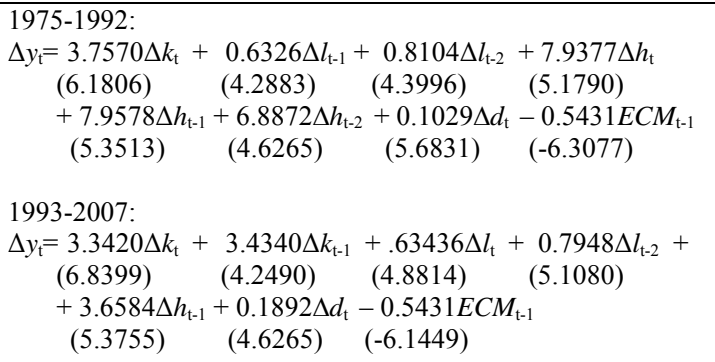 & 0.9002 & 2.4239 & $\begin{array}{c}0.9340 \\
{[0.6269]}\end{array}$ & $\begin{array}{c}2.1896 \\
{[0.3356]}\end{array}$ & $\begin{array}{c}5.5164 \\
{[0.7012]}\end{array}$ \\
\hline GR & 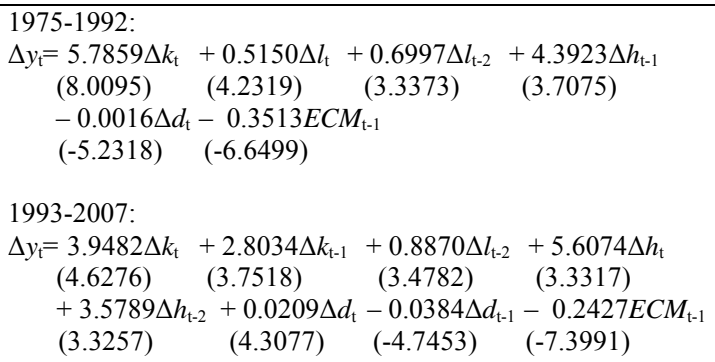 & 0.7556 & 2.1681 & $\begin{array}{c}0.6310 \\
{[0.7294]}\end{array}$ & $\begin{array}{c}1.3139 \\
{[0.5184]}\end{array}$ & $\begin{array}{c}1.7407 \\
{[0.8837]}\end{array}$ \\
\hline IE & 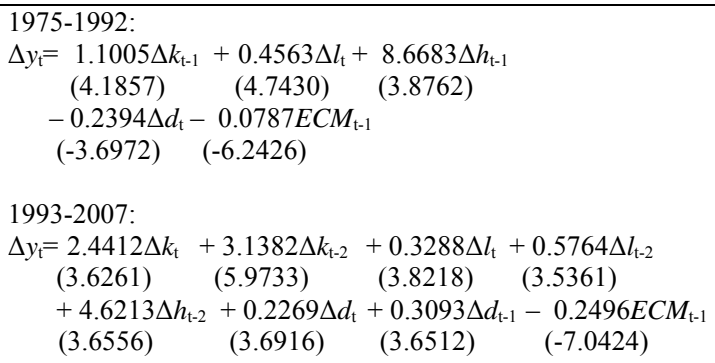 & 0.6302 & 2.6846 & $\begin{array}{c}1.2218 \\
{[0.5428]}\end{array}$ & $\begin{array}{c}4.0204 \\
{[0.1340]}\end{array}$ & $\begin{array}{c}7.1512 \\
{[0.4133]}\end{array}$ \\
\hline IT & 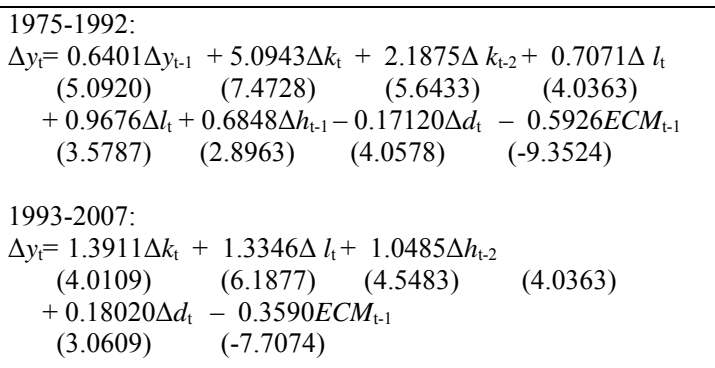 & 0,9249 & 2.1785 & $\begin{array}{c}0.5242 \\
{[0.7695]}\end{array}$ & $\begin{array}{c}1.8796 \\
{[0.3907]}\end{array}$ & $\begin{array}{c}2.8689 \\
{[0.9423]}\end{array}$ \\
\hline $\mathbf{N L}$ & 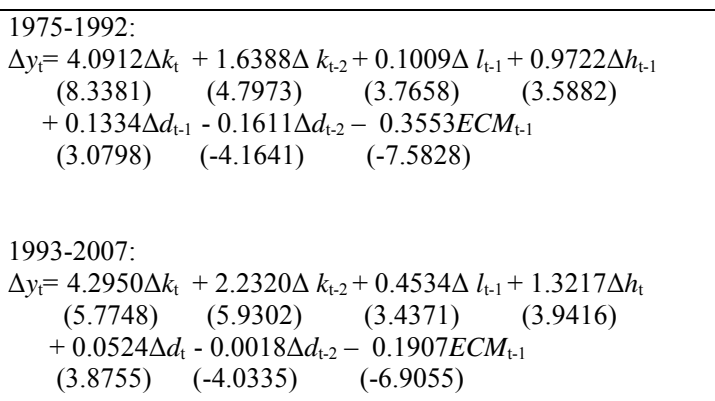 & 0.8974 & 2.1262 & $\begin{array}{c}0.6938 \\
{[0.7069]}\end{array}$ & $\begin{array}{c}1.4946 \\
{[0.4736]}\end{array}$ & $\begin{array}{c}11.3581 \\
{[0.3303]}\end{array}$ \\
\hline
\end{tabular}


Table 6 (continued)

\begin{tabular}{|c|c|c|c|c|c|c|}
\hline Country & & $\begin{array}{c}\text { Adjusted } \\
\mathbf{R}^{\mathbf{2}} \\
\end{array}$ & $\begin{array}{l}\text { DW } \\
\text { Test }\end{array}$ & $\chi_{\mathrm{N}}^{2}$ & $\chi^{2} \mathrm{sc}$ & $\chi_{\mathrm{H}}^{2}$ \\
\hline PT & 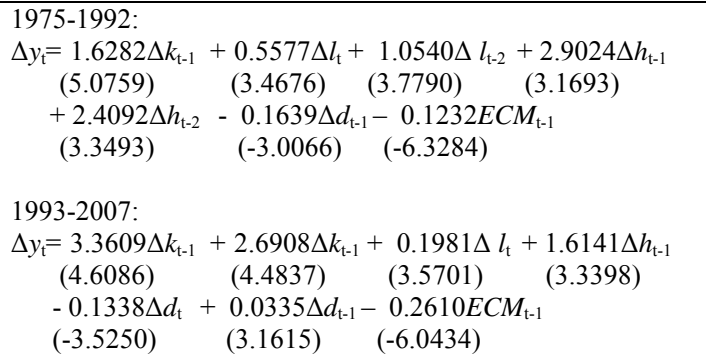 & 0.6612 & 2.1510 & $\begin{array}{c}1.0887 \\
{[05802]}\end{array}$ & $\begin{array}{c}1.2323 \\
{[0.5400]}\end{array}$ & $\begin{array}{c}6.8621 \\
{[0.5516]}\end{array}$ \\
\hline SP & 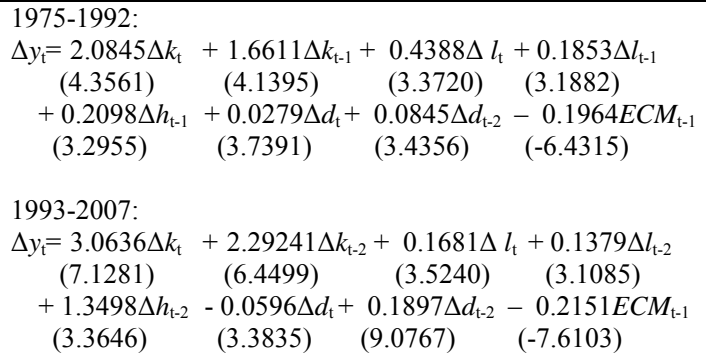 & 0.8823 & 2.1960 & $\begin{array}{c}1.0587 \\
{[0.5890]}\end{array}$ & $\begin{array}{c}2.5897 \\
{[0.5799]}\end{array}$ & $\begin{array}{c}7.1813 \\
{[0.6182]}\end{array}$ \\
\hline
\end{tabular}

Notes: AT, BE, FI, FR, GE, GR, IE, IT, NL, PT and SP stand for Austria, Belgium, Finland, France, Germany, Greece, Ireland, Italy, the Netherlands, Portugal and Spain respectively.

In the ordinary brackets below the parameter estimates are the corresponding $t$-statistics.

$\chi^{2} \mathrm{~N}, \chi^{2} \mathrm{SC}$ and $\chi^{2} \mathrm{H}$ are the Jarque-Bera test for normality, the Breusch-Godfrey LM test for second-order serial correlation and the Breusch-Pagan-Godfrey test for heteroskedasticity. In the square brackets, the associated probability values are given. 
Figure 1. Plot of cumulative sum of recursive residuals

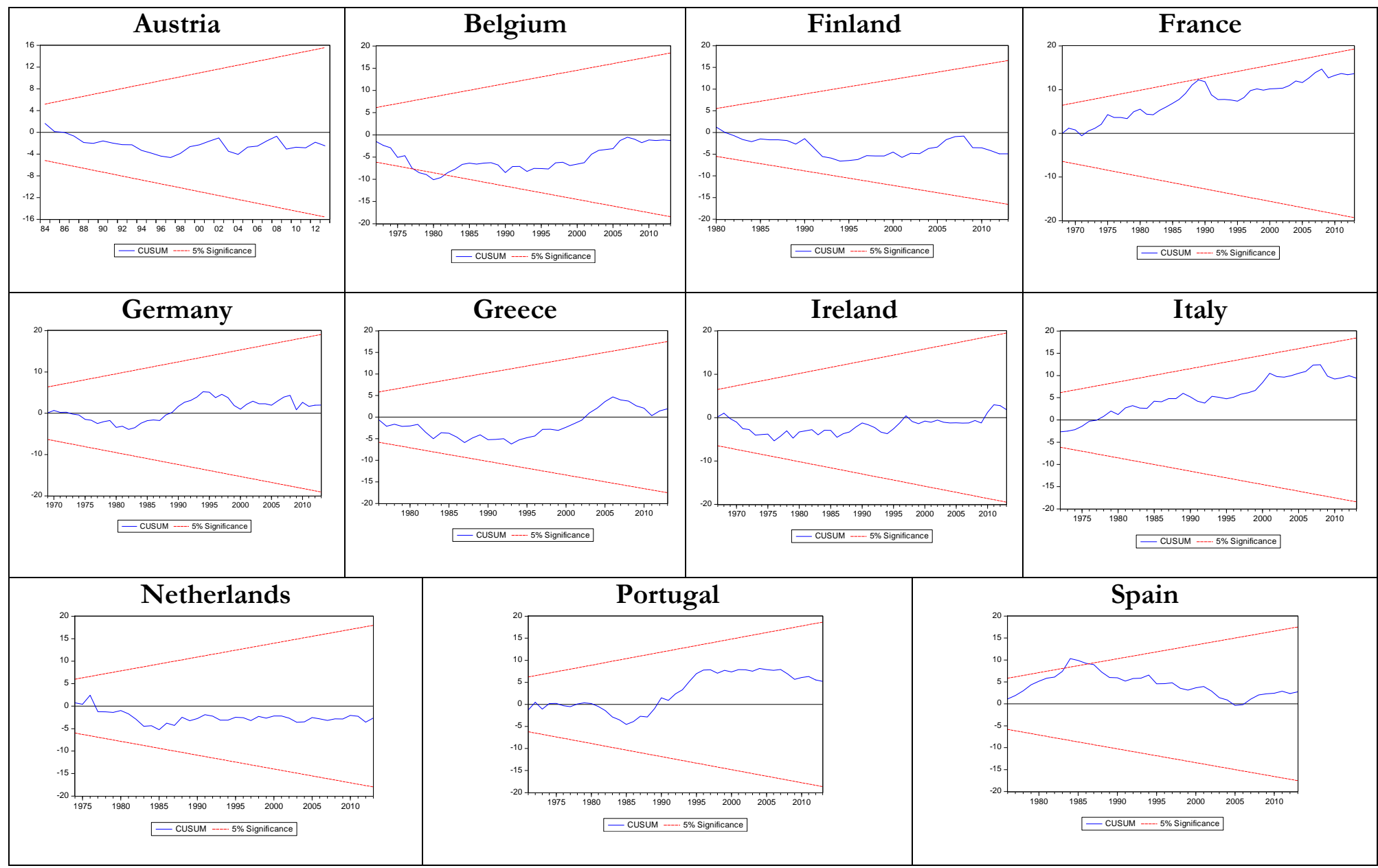

Note: The straight lines represent the critical bounds at a 5\% significance level. Belgium: 1977-1982; Spain: 1983-1987. 
Figure 2. Plot of cumulative sum of squares of recursive residuals

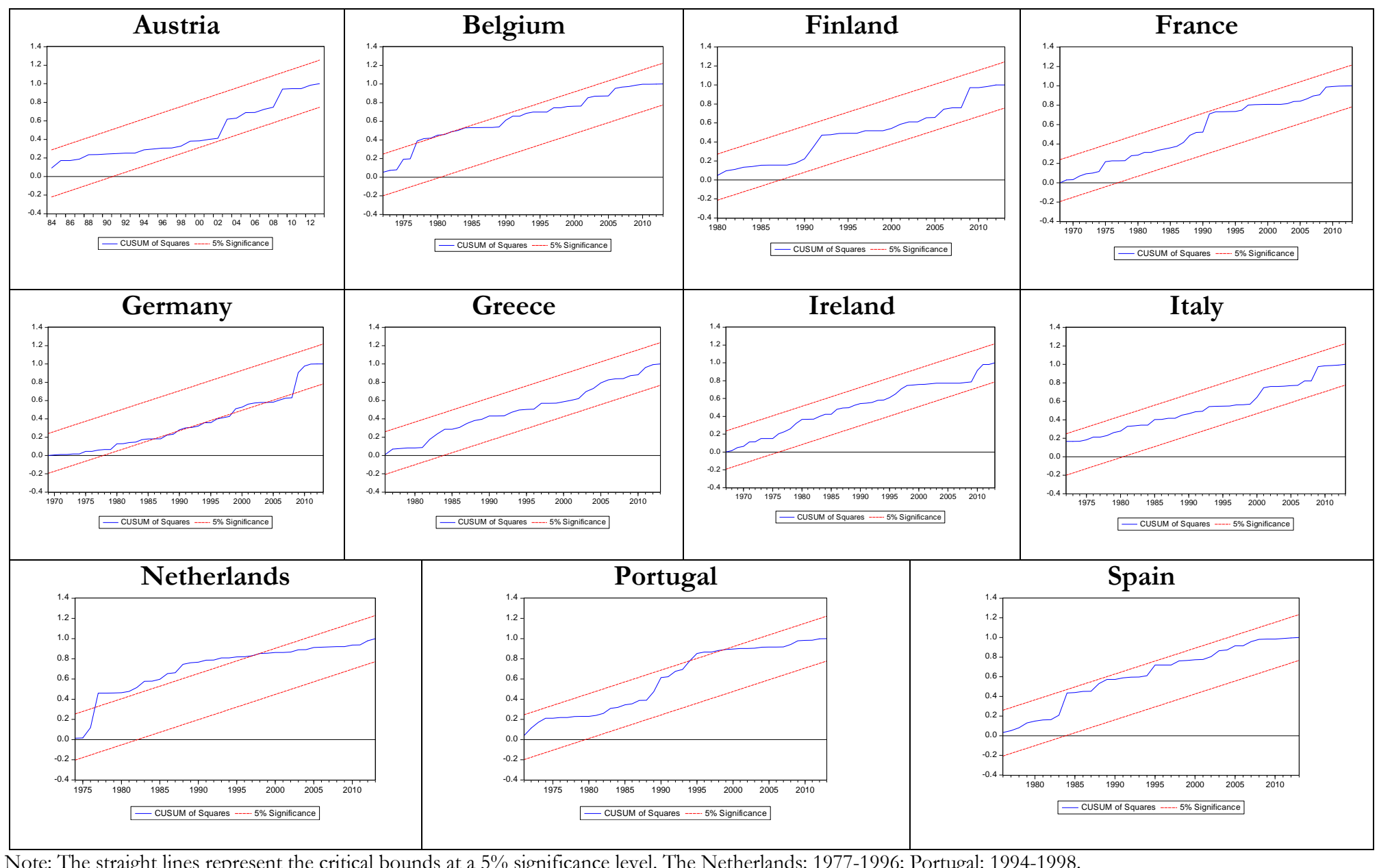

Note: The straight lines represent the critical bounds at a 5\% significance level. The Netherlands: 1977-1996; Portugal: 1994-1998. 
Figure 3. General government consolidated gross debt/GDP

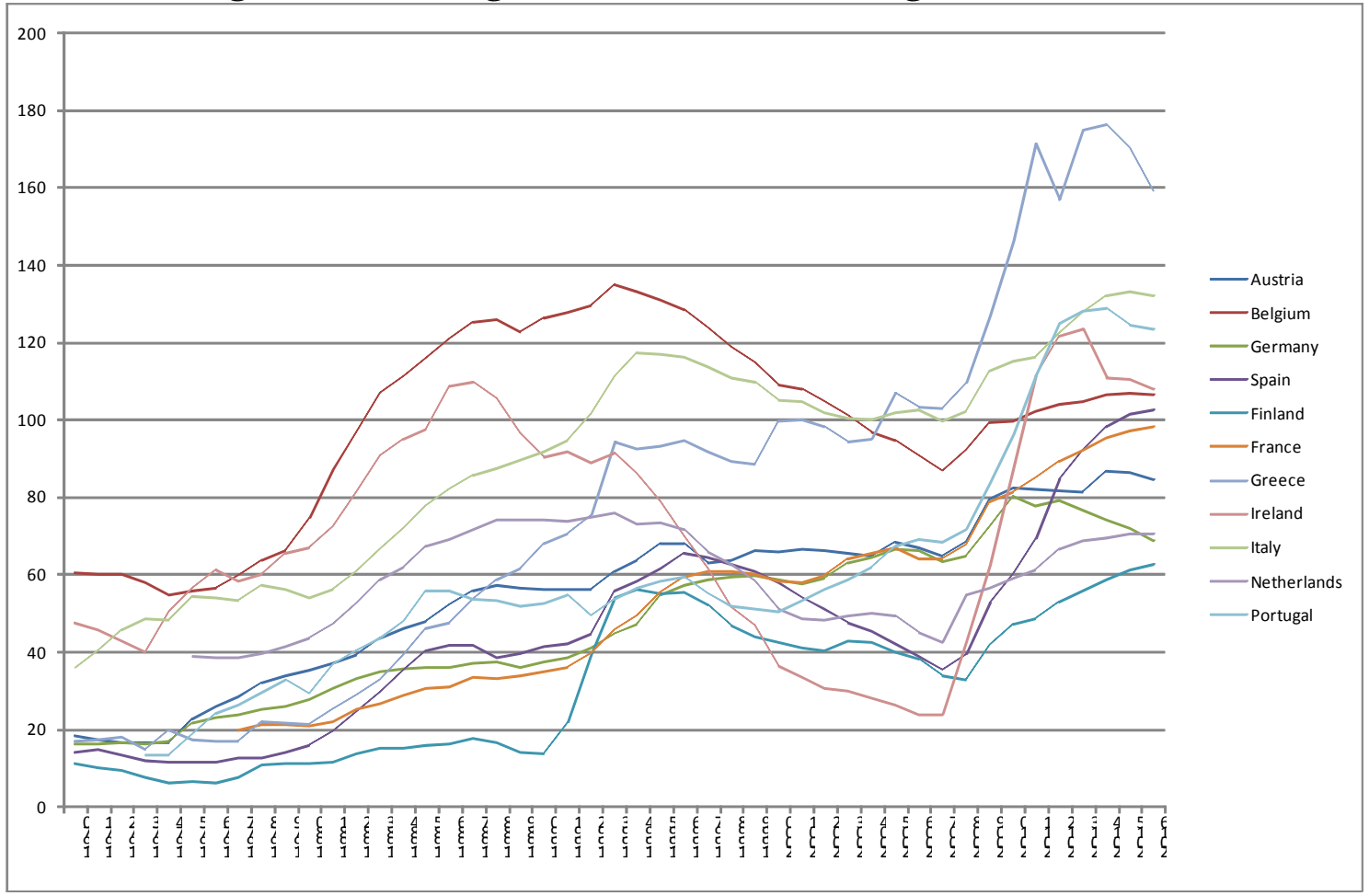

Source: AMECO (European Commission)

Figure 4. GDP rate of growth

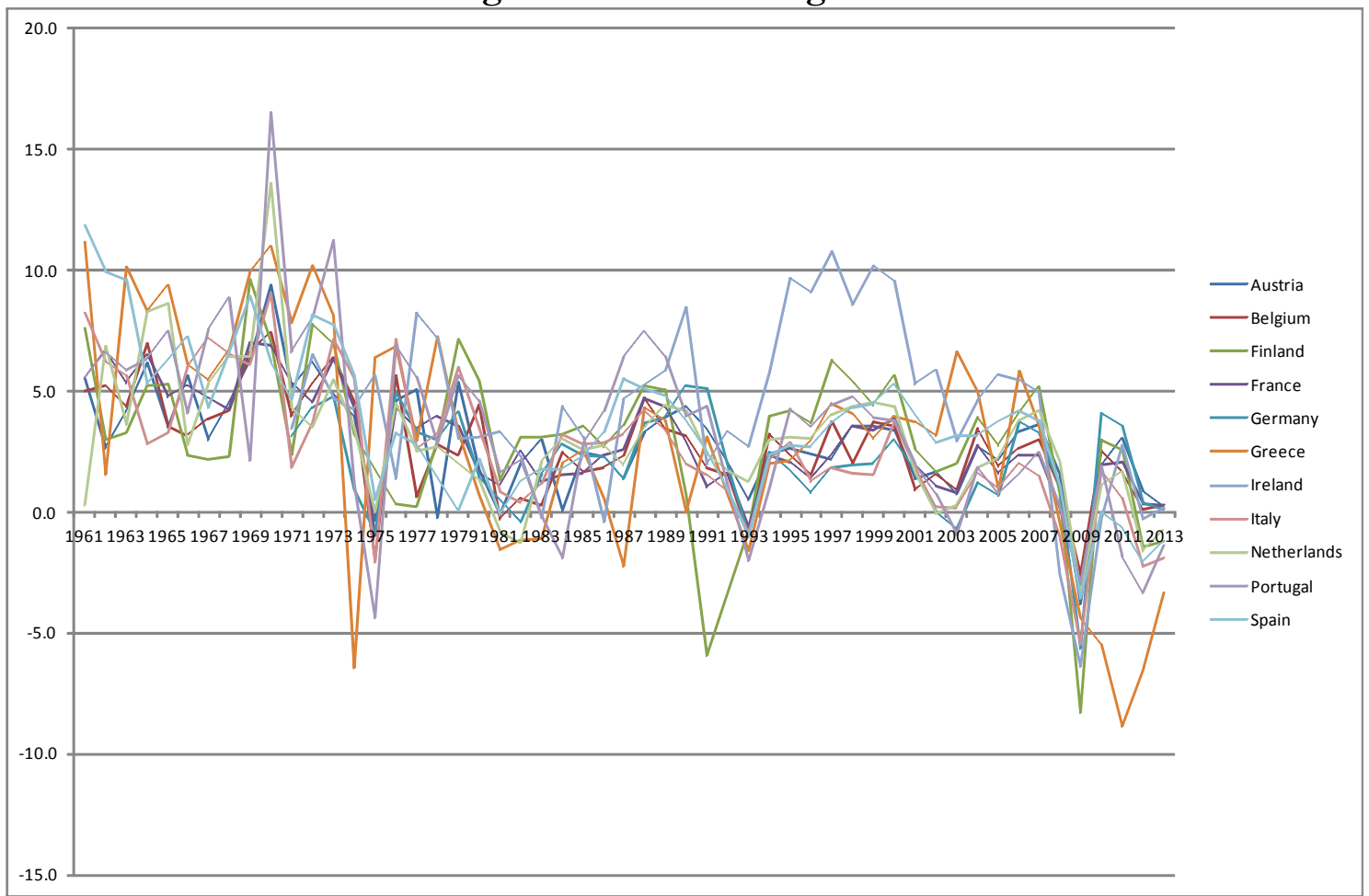

Source: World Development Indicators (World Bank). 


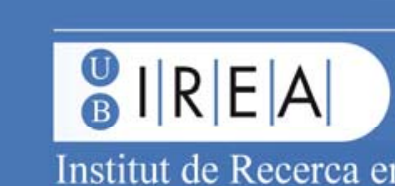

